\title{
Monitoring of inorganic ions, carbonaceous matter and mass in ambient aerosol particles with online and offline methods
}

H. Timonen ${ }^{1}$, M. Aurela ${ }^{1}$, K. Saarnio ${ }^{1}$, A. Frey ${ }^{1}$, S. Saarikoski ${ }^{1}$, K. Teinilä ${ }^{1}$, M. Kulmala ${ }^{2}$, and R. Hillamo ${ }^{1}$

${ }^{1}$ Air Quality Research, Finnish Meteorological Institute, P.O. Box 503, 00101 Helsinki, Finland ${ }^{2}$ Department of Physics, University of Helsinki, P.O. Box 64, 00014 University of Helsinki, Finland

Received: 15 April 2011 - Accepted: 19 October 2011 - Published: 28 October 2011 Correspondence to: H. Timonen (hilkka.timonen@fmi.fi)

Published by Copernicus Publications on behalf of the European Geosciences Union.
Monitoring chemical composition of ambient aerosol

particles

H. Timonen et al.

\section{Title Page}

14

4

Back

Close 


\section{Abstract}

Year-long high timeresolution measurements of major chemical components in atmospheric sub-micrometer particles were conducted at an urban background station in Finland 2006-2007. Ions were analyzed using a particle-into-liquid sampler combined 5 with an ion chromatograph (PILS-IC), organic and elemental carbon (OC and EC) by using a semicontinuos OC/EC aerosol carbon analyzer (RT-OCEC), and $\mathrm{PM}_{2.5}$ mass with a tapered element oscillating microbalance (TEOM). Long time series provides information on differences between the used measurement techniques as well as information about the diurnal and seasonal changes. Chemical mass closure was constructed by comparing the identified aerosol mass with the measured $\mathrm{PM}_{2.5}$. The sum of all components measured online (ions, particulate organic matter (POM), EC) represented only $65 \%$ of the total $\mathrm{PM}_{2.5}$ mass. The difference can be explained by the difference in cutoff sizes $\left(\mathrm{PM}_{1}\right.$ for online measurements, $\mathrm{PM}_{2.5}$ for total mass) and by evaporation of the semivolatile/volatile components. In general, some differences in

15 results were observed when the results of the continuous/semicontinuous instruments were compared with those of the conventional filter samplings. For non-volatile compounds, like sulfate and potassium, correlation between the filter samples and the PILS was good but greater differences were observed for the semivolatile compounds like nitrate and ammonium. For OC the results of the RT-OCEC were on average $10 \%$ larger than those of the filters. When compared to filter measurements, high resolution measurements provide important data on short pollution plumes as well as on diurnal changes. Clear seasonal and diurnal cycles were observed for nitrate and EC.

\section{Introduction}

Atmospheric aerosol particles have an effect on a great variety of atmospheric and en-

25 vironmental processes. Particles decrease visibility, change cloud properties, scatter solar radiation (Seinfeld and Pandis, 1998) and they have a yet undefined effect on human health (Brunekreef and Holgate, 2002; Pope and Dockery, 2006). All these effects
AMTD

4, 6577-6614, 2011

\section{Monitoring chemical composition of ambient aerosol particles}

H. Timonen et al.

\section{Title Page}

Abstract Introduction

Conclusions

Tables

References

\section{Figures}

14

$\rightarrow 1$

4

Back

Close

Printer-friendly Version

Interactive Discussion

Full Screen / Esc 
depend on size, concentration and chemical composition of the particles (Jacobson et al., 2000). Processes in the atmosphere are rapid and the traditional filter collections with long collection times do not provide an adequate picture of the constantly evolving situation. Online methods like the particle-into-liquid sampler (PILS; Orsini et al., 2003), 5 the aerosol mass spectrometer (AMS; Allan et al., 2003) or the semicontinuos OC/EC aerosol carbon analyzer (RT-OCEC; Arhami et al., 2006), provide a good alternative. Online methods have been used to study a wide variety of fast changing properties like gas/particle partitioning, water-solubility and oxygenation state, as well as the diurnal changes and sources of ambient aerosol particles (Kondo et al., 2007; Dunlea et al., 10 2009; Hennigan et al., 2008). Due to their high resolution data, the online methods are also well suited for measurements of ambient aerosol concentrations at moving platforms like airplanes, trains or cars (Kuokka et al., 2007; Sorooshian et al., 2007). The chemical composition of aerosol particles measured with a good timeresolution combined with meteorological and modeling data can be used to assess the variabil15 ity of sources, ambient levels, and human exposure. The errors and uncertainties in filter collections have been extensively studied during the last decades (e.g. Hering and Cass, 1999; Pathak and Chan, 2005; Viana et al., 2006) but the online methods make new challenges. The online sample collection methods are relatively novel and different kinds of sampling artifacts have to be taken into account, and due to the short integration times the concentrations to be determined in these online samples are very low and often close to the determination limits of the analyzing methods (Partshintsev et al., 2009; Timonen et al., 2010).

Year-long continuous measurements of the chemical composition of ambient aerosol particles with a large variety of different instruments were conducted at SMEAR III 25 station from February 2006 to February 2007 . The goal of this study was to explore differences between the used online and filter measurement techniques and to study sampling artifacts and limitations related to each method. A real-time mass closure was calculated from the online results. Additionally, diurnal and seasonal changes of the chemical composition were studied.

\section{AMTD}

$4,6577-6614,2011$

\section{Monitoring chemical composition of ambient aerosol particles}

H. Timonen et al.

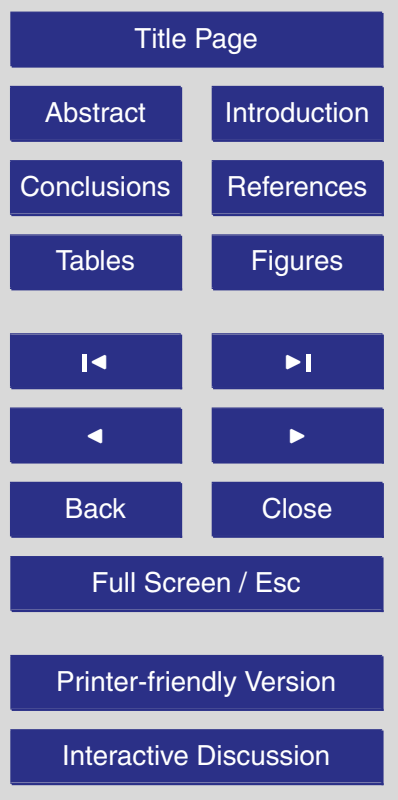




\section{Experimental}

\subsection{Measurement site}

All the measurements were conducted in Helsinki at the SMEAR III station $\left(60^{\circ} 12^{\prime} \mathrm{N}\right.$, $24^{\circ} 58^{\prime} \mathrm{E}, 26 \mathrm{~m}$ above sea level). The SMEAR III station was built for continuous long5 term measurements of basic meteorology, turbulent exchange and chemical and physical properties of atmospheric aerosol particles and gaseous pollutants at an urban background area (Järvi et al., 2009). Helsinki, the capital of Finland, is situated on a fairly flat coastal area by the Baltic Sea. Helsinki together with the neighboring cities of Espoo, Kauniainen and Vantaa forms the Helsinki metropolitan area with more than a million inhabitants. The SMEAR III is located at the Kumpula campus area about five kilometers from Helsinki City centre, next to the University of Helsinki and Finnish Meteorological Institute buildings. Close to the station there is a busy street on the eastern side and a small forested area on the western side. In Finland, the particulate matter concentrations are typically much lower than in Central Europe (Sillanpää et al., 2005), but long-range transported pollution or biomass burning emissions from wild fires elevate concentrations occasionally (Karppinen et al., 2004; Niemi et al., 2004). Based on recent studies, the main local sources of fine particles at SMEAR III are traffic, wood combustion (for residential heating in winter) and secondary aerosol formation (Saarikoski et al., 2008; Timonen et al., 2008; Järvi et al., 2009; Saarnio et al., 2010).

20 Local meteorological data was obtained from the Finnish Meteorological Institute weather station (Vaisala, Milos 500), situated next to the SMEAR III station. Temperature was measured using Pt100 (Pentronic Ab) sensor, relative humidity with HMP45D (Vaisala Oyj) sensor, and global radiation with CM11 (Kipp \& Zonen) sensor.

\subsection{Filter samples and chemical analyses}

$25 \mathrm{PM}_{1}$ filter samples were collected from 9 February 2006 to 28 February 2007 using a filter cassette system. Two pre-fired $\left(12 \mathrm{~h}, 500^{\circ} \mathrm{C}\right)$ quartz fiber filters (Whatman

\section{Monitoring chemical composition of ambient aerosol particles}

H. Timonen et al.

\section{Title Page}

\section{Full Screen / Esc}

Printer-friendly Version

Interactive Discussion 
Q-MA $47 \mathrm{~mm}$ ) were placed in series to a filter cassette. Concentrations measured for the back-up filters were subtracted from those of the front filters by assuming that they were only adsorbed gas-phase components of the sample air (positive artifacts) and the adsorption was equal in the front and back-up filters. The flow rate was ad5 justed to $80 \mathrm{Imin}^{-1}$. In order to remove the particles with an aerodynamic diameter $D_{\mathrm{a}}>1 \mu \mathrm{m}$, four (8-11) stages of the Berner low pressure impactor (BLPI; Berner and Lürzer, 1980) were installed in line prior to the filter cassette. The collection time was $24 \mathrm{~h}$ during the weekdays and $72 \mathrm{~h}$ during weekends. During episodes of elevated particle concentrations shorter collection times $(12 \mathrm{~h}$ ) were used in order to avoid 10 overloading of the filters. Altogether 297 samples were collected during the year-long campaign. A $1 \mathrm{~cm}^{2}$ piece was punched from all the filters for each analyzing method. Organic and elemental carbon (OC and $E C$ ) were determined from the $\mathrm{PM}_{1}$ samples with the thermal-optical carbon analyzer (TOA; Sunset Laboratory Inc., Oregon) using the thermal-optical transmittance method (TOT). The method is described in detail 15 by Saarikoski et al. (2008). Ions $\left(\mathrm{Cl}^{-}, \mathrm{NO}_{3}^{-}, \mathrm{SO}_{4}^{2-}\right.$, oxalate, $\left.\mathrm{NH}_{4}^{+}, \mathrm{K}^{+}\right)$were analyzed using Dionex DX-500 or ICS-3000 ion chromatography systems (Dionex, Sunnyvale, USA). The anion system used $\mathrm{NaOH}$ (KOH for Dionex ICS-3000) eluent with a flow rate of $1.5 \mathrm{ml} \mathrm{min}^{-1}$, a $500 \mu \mathrm{l}$ loop, an ASRS-4 mm electrochemical suppressor and $4 \mathrm{~mm}$ AG11 and AS11 columns. Cations were measured using MSA as an eluent with a flow 20 rate of $1.2 \mathrm{ml} \mathrm{min}^{-1}$, a $300 \mu \mathrm{lloop}$, a CSRS-4 mm suppressor and a CG12A/CS12A column. The runtime was $12 \mathrm{~min}$. Water-soluble organic carbon (WSOC) was analyzed using total-organic carbon analyzer TOC- $\mathrm{V}_{\mathrm{CPH}}$ (Shimadzu). The method is described in detail by Timonen et al. (2008).

Size segregated samples were collected with a micro-orifice uniform deposit im25 pactor (MOUDI; Marple et al., 1991). Altogether 45 collections were made, approximately one in each week during the campaign. The cut-off diameters of the impactor stages were $0.056,0.100,0.18,0.32,0.56,1.00,1.8,3.2$ and $5.6 \mu \mathrm{m}$. Collection time was typically $72 \mathrm{~h}$. Gravimetric mass, WSOC and ions were analyzed from the samples. Details of the collections are published by Timonen et al. (2008).

\section{AMTD}

$4,6577-6614,2011$

\section{Monitoring chemical composition of ambient aerosol particles}

H. Timonen et al.

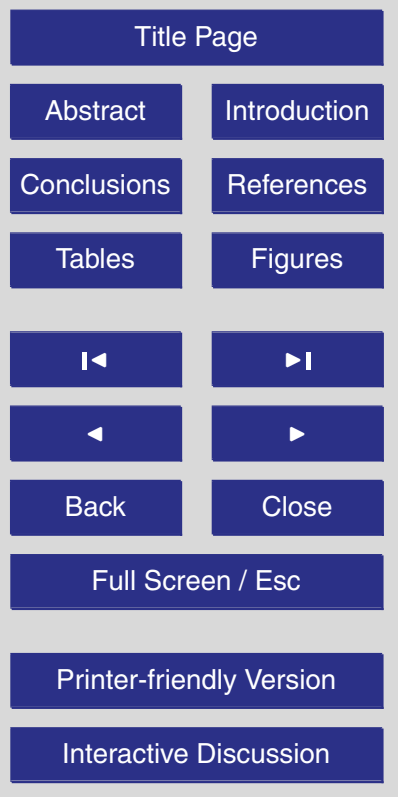




\subsection{Online methods}

Particle-into-liquid sampler combined with two Dionex ICS-2000 ion chromatographs (Dionex, Sunnyvale, USA) was used to collect ambient aerosol samples and to analyze the concentrations of major ions online from 9 February 2006 to 28 February 2007. 5 PILS-IC was not measuring from 28 November 2006 to 26 January 2007 due to technical problems. A virtual impactor (Vl; Loo and Cork, 1988) with a cut-off size of $1.3 \mu \mathrm{m}$ was used to remove coarse particles prior to the PILS. Gaseous compounds (ammonia and acidic gases) were removed prior to the PILS with three annular denuders, one coated with phosphoric acid $\left(\mathrm{H}_{3} \mathrm{PO}_{4} 3 \%\right)$ and two with potassium hydroxide ( $\left.\mathrm{KOH} 1 \%\right)$. 10 The denuders were changed every second week to ensure that all gaseous compounds were effectively removed. The operation principle of the PILS is described in detail in Orsini et al. (2003). Shortly, aerosol and water steam is simultaneously fed to the PILS, where particles grow as they move across a conical shape cavity. On the other end of the cavity the particles are impacted to a quartz glass impaction surface. The surface 15 is rinsed with water (Milli-Q, Millipore Gradient A10) containing a known concentration of lithium fluoride (LiF) as an internal standard. During the campaign the impaction surface was regularly cleaned to remove water-insoluble particles (mainly soot) from the impaction surface. An 8-channel peristaltic pump (Watson Marlow, 205S, USA) was used to maintain the liquid flows $\left(1.25 \mathrm{ml} \mathrm{min}^{-1}\right.$ water for steamer, $0.25 \mathrm{ml} \mathrm{min}^{-1}$ LiF solution) and to deliver the sample from the debubbler to the ion chromatographs (0.1 $\mathrm{ml} \mathrm{min}^{-1}$ for each instrument). The liquid from the PILS was directly fed to the loops of two Dionex ICS-2000 ion chromatographs (Dionex, Sunnyvale, USA). Due to short sample collection times $(15 \mathrm{~min})$ in PILS-IC system, larger $1000 \mu \mathrm{ll}$ loops were used to collect representative samples for subsequent IC analyzes.

With the PILS-IC system the concentrations of $\mathrm{Cl}^{-}, \mathrm{NO}_{3}^{-}, \mathrm{SO}_{4}^{2-}, \mathrm{Na}^{+}, \mathrm{NH}_{4}^{+}, \mathrm{K}^{+}$, oxalate and methane sulphonate (MSA) could be determined with 15 min timeresolution. The quantification limit for the ions was $2.5 \mathrm{ng} \mathrm{ml}^{-1}$, which equals to the air concentration of $0.05 \mathrm{\mu g} \mathrm{m}^{-3}$. The uncertainty of the PILS results was estimated to be $15 \%$ for all analyzed ions.
AMTD

$4,6577-6614,2011$

\section{Monitoring chemical composition of ambient aerosol particles}

H. Timonen et al.

\section{Title Page}


A semicontinuous OC/EC carbon aerosol analyzer was used continuously to measure the concentrations of elemental and organic carbon. The timeresolution of the instrument was set to three hours and the sample flow was $9.21 \mathrm{~min}^{-1}$ to collect representative sample for the subsequent thermal analysis. A cyclone was used to cut 5 off particles with aerodynamic diameter $D_{\mathrm{a}}>1 \mu \mathrm{m}$. A parallel plate carbon denuder was used inline prior to the instrument to remove organic gases. The method is described in detail by Saarikoski et al. (2008). Shortly, during one measurement cycle the instrument collects a sample for $164 \mathrm{~min}$. After the sampling period, the deposited particles are heated in a quartz oven where the elemental and organic carbon concen10 trations are individually quantified. During the first phase of the analysis the sample is purged with helium and the temperature is raised in steps from $650^{\circ} \mathrm{C}$ to $850{ }^{\circ} \mathrm{C}$. During this phase all organic carbon is vaporized. In the second phase the sample is purged with helium-oxygen mixture while the temperature is again raised in steps from $650^{\circ} \mathrm{C}$ to $850^{\circ} \mathrm{C}$ to oxidize all elemental carbon. In the first measurement phase py15 rolysis converts part of the organic carbon to a light absorbing substance, resembling EC (Viidanoja et al., 2002), which needs oxidation and is measured only in the second phase. The laser transmission value is used to separate the pyrolyzed OC from EC. The split is adjusted so that when the laser reaches its original value, all the pyrolyzed carbon has been removed from the filter. All the vaporized carbon compounds formed ide. The amount of carbon dioxide is quantified with a non-dispersive infrared (NDIR) detector. The blank value (sum of instrumental blank ( 3 min sample at 03:00) value $0.24 \pm 0.079 \mu \mathrm{gC} \mathrm{m}^{-3}$ and measured denuder breakthrough value $0.52 \pm 0.10 \mu \mathrm{gC} \mathrm{m}^{-3}$ (Saarikoski et al., 2008)) was subtracted from the TC results.

25 In addition to thermal EC and OC measurements, the RT-OCEC measures optical EC with one minute timeresolution using the laser light transmission. Due to the small average concentrations in Helsinki, the measurements of total carbon (TC; Thermal $\mathrm{EC}+\mathrm{OC}$ ) and optical EC were considered more reliable and therefore the "Optical OC" results (Optical OC $=$ TC-optical EC) were used in the comparison. The uncertainty of
AMTD

$4,6577-6614,2011$

\section{Monitoring chemical composition of ambient aerosol particles}

H. Timonen et al.

\section{Title Page}

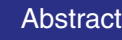


OC and EC results was estimated to be $20 \%$.

Tapered Element Oscillating Microbalance $\left(\right.$ TEOM $^{\complement}$ 1400a, Patashnick and Rupprecht, 1991; Allen et al., 1997) was used to continuously measure the $\mathrm{PM}_{2.5}$ mass concentration. The TEOM was equipped with a Filter Dynamics Measurement System 5 (FDMS). In the FDMS, for the first six minutes the flow is directed through the Sample Equilibration System (SES) dryer to TEOM and the nonvolatile mass is measured. For the next six minutes the flow goes through a filter, where all the particles are removed, and the mass volatilized from the collection filter is measured. The mass evaporated from the filter is added to nonvolatile mass to achieve a real $\mathrm{PM}_{2.5}$ concentration. A 10 virtual impactor (VI, Loo and Cork, 1988) was used prior to the TEOM to cut off large particles $\left(D_{\mathrm{p}}>2.5 \mu \mathrm{m}\right)$. The uncertainty of the TEOM results was estimated to be $10 \%$.

A single-wavelength aethalometer (model AE-42, Magee Scientific; Hansen et al., 1984) using the wavelength of $880 \mathrm{~nm}$ was used to measure the black carbon concentrations. Time-resolution of the measurements was $5 \mathrm{~min}$ and the flow rate was

$155 \mathrm{I} \mathrm{min}-1$. A cyclone was used to remove particles larger than $2.5 \mu \mathrm{m}$ in aerodynamic diameter. Black carbon equivalent mass concentrations were calculated from the absorption measurements of the aethalometer using a mass absorption efficiency of $16.6 \mathrm{~m}^{2} \mathrm{~g}^{-1}$. The uncertainty of the results was estimated to be $10 \%$.

\subsection{Comparison between online instruments and filter sampling}

20 The results of semicontinuous/continuous measurements (RT-OCEC, PILS-IC, TEOM and aethalometer) were compared against those obtained from the $\mathrm{PM}_{1}$ filter measurements. Resulting ratios of $\mathrm{PM}_{1}$ filter to online collection ( $r$; Pearson correlation) have been collected to Table 1 . Sampling time for the $\mathrm{PM}_{1}$ filters was approximately $24 \mathrm{~h}$ during weekdays and $72 \mathrm{~h}$ in weekends and therefore the results of the RT-OCEC, PILS-IC 25 and TEOM were averaged to corresponding time periods. Optical EC from RT-OCEC was compared with $\mathrm{BC}$ measured with the aethalometer. The measurement period for that comparison was three hours: the timeresolution of RT-OCEC . The results from the comparisons are discussed below.
AMTD

4, 6577-6614, 2011

\section{Monitoring chemical composition of ambient aerosol particles}

H. Timonen et al.

\section{Title Page}




\section{Results and discussion}

\subsection{General features of the measurement period}

The concentrations of the main chemical components (ions, $\mathrm{OC}$ and $\mathrm{EC}$ ) in aerosol particles, were measured with various online methods (RT-OCEC, PILS-IC, TEOM 5 and aethalometer) at the urban background station for 13 months (9 February 200628 February 2007). The TEOM had been operated at SMEAR III since October 2004, but the RT-OCEC measurements did not start before June 2006. Due to technical problems, some of the instruments did not run all the time. Online instruments, their measurement periods and cut off sizes, and the average and maximum values for each

10 measured component are given in Table 2. Daily $\mathrm{PM}_{1}$ filter samples were collected parallel to the online measurements. The concentrations of ions, WSOC, OC and EC were measured from the filters. Measured components/properties, applied analytical methods, and the average and maximum results for the filter samples are presented in Table 3. The results of the backup filters were subtracted from the results of the front filter in order to take into account the gaseous compounds absorbed on the filters. The backup to front filter - ratios for ions were $1.3 \pm 1.8 \%$ (ammonium), $3.9 \pm 3.7 \%$ (potassium), $4.4 \pm 7.1 \%$ (sulfate), $4.3 \pm 5.0 \%$ (oxalate) and $42 \pm 33 \%$ (nitrate). For WSOC and $\mathrm{OC}$ the backup to front filter -ratios were $5.6 \pm 6.4 \%$ and $10 \pm 6.6 \%$, respectively. All chemical components investigated are discussed separately in the following sections.

\subsection{PM concentrations}

TEOM 1400a equipped with the FDMS system was used to measure the $\mathrm{PM}_{2.5}$ mass concentrations. $\mathrm{PM}_{2.5}$ mass used in the calculations is the FDMS $\mathrm{PM}_{2.5}$ mass, i.e. it contains both non-volatile mass and the mass of compounds evaporated from the

25 TEOM filter. $\mathrm{PM}_{2.5}$ measurements with the TEOM equipped with both the SES and the FDMS systems have been shown to compare very well with other real-time automatic
AMTD

4, 6577-6614, 2011

\section{Monitoring chemical composition of ambient aerosol particles}

H. Timonen et al.

\section{Title Page}

Abstract Introduction

Conclusions

References

Tables Figures

14 $\Delta$

4

Back Close

Printer-friendly Version

Interactive Discussion

Full Screen / Esc 
analyzers accounting semivolatile matter (Grover et al., 2006; Wilson et al., 2006). During this campaign (9 February 2006-28 February 2007) the $\mathrm{PM}_{2.5}$ mass concentration was on average $13.8 \pm 11.4 \mu^{-3} \mathrm{~m}^{-3}$ (average \pm standard deviation, Table 2). Maximum $\mathrm{PM}_{2.5}$ concentrations (up to $180 \mu \mathrm{g} \mathrm{m}^{-3}$ ) were observed during two wild fire burning 5 episodes, first in April-May and the second in August 2006. The details of these episodes have been published by Saarikoski et al. (2007) and Saarnio et al. (2010). The ratio between non-volatile mass and $\mathrm{PM}_{2.5}$ was $0.82 \pm 0.52$, suggesting that on average $18 \%$ of mass was volatile at the temperature of the TEOM SES $\left(30^{\circ} \mathrm{C}\right.$; in Finland the temperature is for most of the time below $30^{\circ} \mathrm{C}$, thus this represents the 10 maximum value for semivolatile matter). The measured $\mathrm{PM}_{2.5}$ mass concentrations were similar to those measured typically in Finland at urban background sites (Mean $\mathrm{PM}_{2.5}$ values in 2001 in urban and urban background sites were 9.6 and $8.2 \mu \mathrm{g} \mathrm{m}^{-3}$; Laakso et al., 2003).

The TEOM results were compared to the 24-h filter measurements carried out in par15 allel at the SMEAR III. For filter measurements the mass was calculated as a sum of all ions, EC and particulate organic matter (POM), which was calculated from the OC concentration ( $\mathrm{POM}=1.6^{\star} \mathrm{OC}$, Turpin et al., 2001; Saarnio et al., 2010). The average mass concentration for $\mathrm{PM}_{1}$ was $7.8 \pm 6.5 \mu \mathrm{g} \mathrm{m}^{-3}$. The ratio between $\mathrm{PM}_{1}$ (filters) and $\mathrm{PM}_{2.5}$ (TEOM) was $0.62 \pm 0.51$. The difference is caused likely by the evaporation of 20 semivolatile compounds from the $\mathrm{PM}_{1}$ filter and the difference in the cutoff sizes, $\mathrm{PM}_{1}$ and $\mathrm{PM}_{2.5}$. The ratio between the $\mathrm{PM}_{1}$ filter and TEOM $\mathrm{PM}_{2.5}$ nonvolatile mass was $0.70 \pm 0.26$. The mass between $\mathrm{PM}_{1}$ and $\mathrm{PM}_{2.5}$ can be evaluated from the MOUDI results. The mass ratios between $\mathrm{PM}_{1} / \mathrm{PM}_{1.8}$ and $\mathrm{PM}_{1} / \mathrm{PM}_{3.2}$ in MOUDI were $0.83 \pm 0.10$ and $0.68 \pm 0.15$, indicating that on average $17 \%$ of $\mathrm{PM}_{1.8}$ mass was between $\mathrm{PM}_{1}$ and $25 \mathrm{PM}_{1.8}$ and $32 \%$ of $\mathrm{PM}_{3.2}$ mass between $\mathrm{PM}_{1}$ and $\mathrm{PM}_{3.2}$. Assuming that the mass is equally distributed between $\mathrm{PM}_{1.8}$ and $\mathrm{PM}_{3.2}$, the mass between $\mathrm{PM}_{1}$ and $\mathrm{PM}_{2.5}$ would be $25 \%$ of $\mathrm{PM}_{2.5}$ mass that is close to the observed difference between $\mathrm{PM}_{1}$ and $\mathrm{PM}_{2.5}(30 \%)$. Some uncertainty to this approach is due to the fact that the collection efficiency curves in the impactor are not step functions, but this is difficult to
AMTD

4, 6577-6614, 2011

\section{Monitoring chemical composition of ambient aerosol particles}

H. Timonen et al.

\section{Title Page}

Abstract Introduction

Conclusions

Tables References Figures

14

4

Back

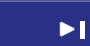

>

Close

Printer-friendly Version

Interactive Discussion 
quantify. The real-time mass closure (constructed for the three hour periods) will be discussed in detail later in this paper.

\subsection{Results of $\mathrm{PM}_{1}$ measurements versus PILS results}

4, 6577-6614, 2011

PILS-IC was used to measure the concentrations of major ions with 15 minutes 5 timeresolution from 9 February 2006 to 28 March 2007. Sulfate was the most abundant ion, with an average concentration of $1.74 \mu^{-3} \mathrm{~m}^{-3}$ (Table 2). The average concentrations for $\mathrm{NO}_{3}^{-}, \mathrm{NH}_{4}^{+}$and $\mathrm{K}^{+}$were $0.77,0.85$ and $0.10 \mu \mathrm{g} \mathrm{m}^{-3}$, respectively. The concentrations of ammonium and sulfate correlated strongly $(r=0.88)$. For sulfate the concentrations were well above the quantification limit and the PILS-IC results agreed 10 well with those from the filter samplings ( $r=0.86$; Table 1; Fig. 1). However, for sulfate the results of the filter samples were on average $18 \%$ higher than the PILS-results. Compared to sulfate, substantially larger differences between the PILS and $\mathrm{PM}_{1}$ results were observed for nitrate and ammonium. The PILS-IC concentrations for nitrate were systematically larger than those in the filters with no clear seasonal variation (Fig. 1).

15 The largest nitrate concentrations were detected in winter and spring, whereas very low concentrations were measured in summer. Sorooshian et al. (2006) has tested the ability of the PILS to collect nitrate by producing ammonium nitrate and collecting it with the PILS. They found that the PILS measurements are within $4 \%$ of the Differential Mobility Analyzer (DMA) derived mass concentrations for nitrate. Additionally, in some 20 studies, where the nitrate concentrations have been measured simultaneously with the AMS and PILS (e.g. Bae et al., 2007; Timonen et al., 2010), a good correlation between the two instruments has been typically observed, indicating that the PILS-IC can be assumed to measure nitrate acceptably. The difference between the $\mathrm{PM}_{1}$ filter collections and the PILS-IC measurement for nitrate is likely caused by nitrate evaporating 25 from the filters during the collection and storage (in freezer). Also the large amounts of nitrate observed in the quartz backup filter, indicate that substantial amounts of nitrate evaporates from the front filter during the collection. For nitrate the difference between PILS and $\mathrm{PM}_{1}$ filter results was on average $41 \%$ which is very close to the amount

\section{Monitoring chemical composition of ambient aerosol particles}

H. Timonen et al.

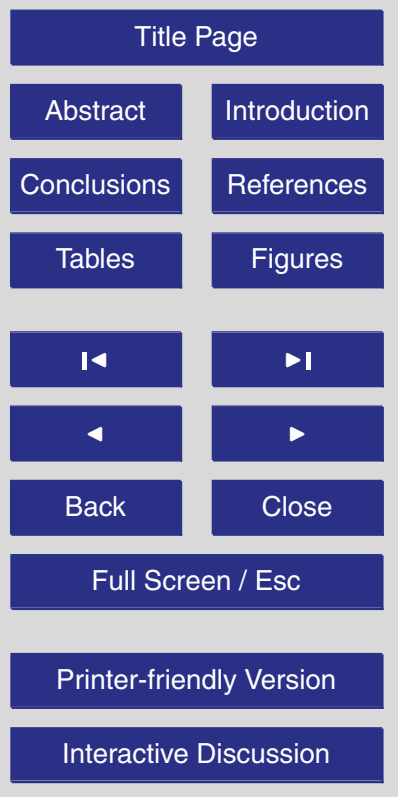


of nitrate observed in the backup filter $(42 \pm 33 \%)$. That percentage is lower than the value of Pakkanen et al. (2001) who found that $66 \%$ of nitrate was evaporated from Teflon filters (nitrate was analyzed from nylon backup filters) in Helsinki. In this study quartz fiber filters were used, which can be assumed to decrease the evaporation of 5 nitrate due to the thicker and more porous texture compared to the Teflon filter material. The average $\mathrm{PM}_{1}$ filter to PILS-IC ratio for nitrate had large variation from 0.34 to 1.0 (Fig. 2), suggesting that the percentage of nitrate evaporated from the filter varied possibly due to the chemical composition or meteorological conditions like temperature or humidity. The amount of ammonium that was evaporated from filter had very differ10 ent time trend from that of nitrate. For ammonium the $\mathrm{PM}_{1}$ filter to PILS-IC ratio was larger during the cold period and smaller in summer (June-August, Fig. 2). On average $\mathrm{PM}_{1}$ filters gave slightly smaller concentrations for ammonium than the PILS-IC (Figs. 1 and 2).

The concentrations of potassium and oxalate were very low $\left(0-0.1 \mu \mathrm{g} \mathrm{m}^{-3}\right)$ for 15 most of the year, being in the PILS-IC measurements above the quantification limit only $20 \%$ and $30 \%$ of time, respectively. Elevated potassium concentrations (up to $0.5 \mathrm{\mu g} \mathrm{m}^{-3}$; not shown) were measured only during the two biomass burning episodes: in April-May and August (Saarikoski et al., 2007; Saarnio et al., 2010). For potassium the results of the PILS-IC and PM $_{1}$ filters agreed very well $(r=0.9$; Table 1$)$.

20 For oxalate a good correlation was observed only for concentrations above $0.1 \mu \mathrm{g} \mathrm{m}^{-3}$ $(N=15)$. For lower concentrations, the results of the PILS-IC were 2-3 times smaller than the $\mathrm{PM}_{1}$ filter results. At low concentrations $\left(0.05-0.1 \mu \mathrm{g} \mathrm{m}^{-3}\right)$, near the compounds' quantification limits, the IC results are highly uncertain and therefore it is not possible to draw any conclusions based on them. For sodium and chloride the concentration in the PILS-IC were for most of the time (>80\%) below the quantification limit as can be expected for fine PM fraction.

Results of the PILS have been compared with filter samples only in a few other studies. Typically the filter results for sulfate and ammonium correlate well with the PILS, but for nitrate the agreement is poor (Orsini et al., 2003; Kuokka et al., 2007).
AMTD

$4,6577-6614,2011$

\section{Monitoring chemical composition of ambient aerosol particles}

H. Timonen et al.

\section{Title Page}


Ma et al. (2004) have compared the ion concentrations collected by a micro-orifice impactor and by the PILS. They found that the correlations between the concentrations measured by the PILS and the impactor were relatively high, but the concentrations measured with the PILS were lower by $10 \pm 5 \%, 11 \pm 8 \%$, and $18 \pm 5 \%$ for sulfate,

5 ammonium, and nitrate, respectively. In this study the sulfate measured from the filter was $18 \%$ higher whereas ammonium and nitrate concentrations were 9.1 and $39 \%$ lower, respectively, than those in the PILS results.

Laboratory tests have shown that the collection efficiency of PILS exceeds $97 \%$ for olive oil particles in the size range of $30 \mathrm{~nm}-10 \mu \mathrm{m}$ (Orsini et al., 2003). However, the 10 collection efficiency in the PILS depends on the volatility of the compounds since the semivolatile species evaporate in the PILS as a result of latent heat of condensation and convective heating of the sampled air (Sorooshian et al., 2006). The collection efficiency has been shown to be lower for ammonium ( $88 \%$ ) that has been theoretically shown to be the most vulnerable to volatilization (Sorooshian et al., 2006). In addition 15 to the volatilization, other differences in the two methods, PILS and PM 1 filters, are likely causing part of the variation seen in the results of this study. In filter methods, particles stay in the filter material long time after collection. Evaporation of semivolatile compounds from the filter and adsorption of gases on the filter material during the collection can have a large effect on the results (Hering and Cass, 1999; Viana et 20 al., 2006). In the PILS the sample is mixed with supersaturated water-vapour and subsequently impacted to quartz impaction plate within seconds (Orsini et al., 2003).

\subsection{Ion balance in PILS and $\mathrm{PM}_{1}$ filter collections}

The equivalent ratio of cations to anions was calculated for the $\mathrm{PM}_{1}$ filter samples and the PILS results (Fig. 3). For $\mathrm{PM}_{1}$ the ratio was quite stable being on average $0.9 \pm 0.2$. 25 For PILS the ratio was on average $1.05 \pm 0.3$ being higher in summer (from July to September) than in winter. The maximum cations/anions -ratio (monthly average 1.4) was observed during the biomass burning episode in August (see Saarnio et al., 2010). The amount of excess ammonium was calculated from the ammonium concentration

\section{AMTD}

4, 6577-6614, 2011

\section{Monitoring chemical composition of ambient aerosol particles}

H. Timonen et al.

\section{Title Page}

Full Screen / Esc

Printer-friendly Version

Interactive Discussion 
by subtracting first the amount of ammonium sulfate (for simplicity all ammonium is assumed to be ammonium sulphate without contribution of ammonium bisulphate. If part of sulphate would be in the form of ammonium bisulphate the amount of excess ammonium would be larger), then ammonium nitrate and at last ammonium chloride.

5 It was observed that for most of the time ammonium was in the form of ammonium sulfate and ammonium nitrate. In summer, from June to September, substantial amount of excess ammonium was observed. The reason why the ammonium results from the PILS are larger than the ammonium measured from the filter in summertime is unclear. It is possible that in summer more ammonium and nitrate is evaporated from the fil10 ters than in other seasons, but it is does not explain the large cations/anions -ratio. Another possible explanation would be the breakthrough of gaseous artifacts if the denuders do not properly remove gaseous ammonia. During the campaign the denuders were changed every two weeks, and this cycle should have been seen in the PILS concentrations if the denuder efficiency had decreased during the two week period. 15 Temporal high cation/anion -ratios have been observed also in other studies. Weber et al. (2001) observed that the cation/anion ratio seem to be dependent on the particle source. They measured cation/anion -ratios below one for local pollution episodes and cation/anion -ratios up to four for the clean air masses with low $\left(10 \mu \mathrm{g} \mathrm{m}^{-3}\right)$ ambient aerosol concentrations.

20 The amount of excess ammonium increased as the temperature increased (Fig. 4). At the same time as the relative amount of ammonium increased the contribution of nitrate to the total mass decreased (Fig. 4). The temperature dependency of nitrate is likely caused by nitrate partition to the gas phase as the temperature increases.

\subsection{Online measurements of OC and EC}

25 The concentrations of $\mathrm{OC}$ and EC were measured continuously using a semicontinuous OC/EC aerosol carbon analyzer (Saarikoski et al., 2008). The average concen-

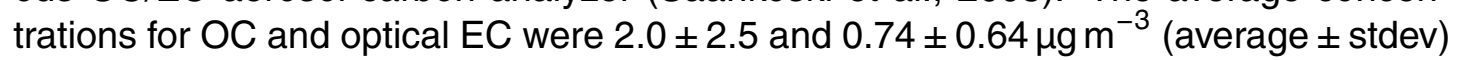
(Table 2). OC correlated with the $\mathrm{PM}_{2.5}(r=0.70)$, but no other correlations between

\section{AMTD}

$4,6577-6614,2011$

\section{Monitoring chemical composition of ambient aerosol particles}

H. Timonen et al.

\section{Title Page}


the chemical components or between the chemical components and the $\mathrm{PM}_{2.5}$ were found. Contrary to the ions, for $\mathrm{OC}$ the semicontinuous and the filter sampling methods gave quite similar results. The results of the RT-OCEC were on average $10 \%$ larger than those of the filters for OC (Table 1) but the correlation between the RT-OCEC and 5 the filter sampling was good $(R=0.98)$. Similar behavior for OC has been observed also by Sciare et al. (2010). In both methods (RT-OCEC and $\mathrm{PM}_{1}$ filters collections) particles were collected on filters, but in the RT-OCEC gas-phase components were removed prior to the filter with a parallel plate carbon denuder. In the filter sampling the absorption of gas-phase compounds on filters was taken into account by subtracting 10 the value of the backup filter from the result of the front filter. In addition to the gaseous compounds, part of the semivolatile organic components evaporated from the front filter were subsequently absorbed on the backup filter and considered as the gas-phase components and subtracted from the particulate-phase OC. That can underestimate the amount of particulate-phase OC determined from the filter samples. In the RT15 OCEC semivolatile organic components were included in OC since the two filters were used back to back and analyzed simultaneously. One major difference between online and filter measurements was the storage time. The filter samples were stored in freezer from days to weeks prior to their analysis, whereas the online samples were analyzed directly after the collection. The efficiency of the denuder in front of the RT-OCEC can also explain partly the larger concentrations of OC measured with the RT-OCEC than using the filter sampling. An average of the measured denuder break-through value and the blank values $\left(0.80 \mathrm{\mu g} \mathrm{m}^{-3}\right)$ were subtracted from the RT-OC. However, denuder efficiency may change in time or it can depend on the concentrations of gaseous components. The more detailed analyzes of the sources and the behavior of OC during this campaign has been published by Saarikoski et al. (2008).

For optical EC, the RT-OCEC and the filter measurements gave comparable results with a high correlation coefficient $(r=0.89$; Table 3$)$. The optically measured EC was compared with black carbon $(\mathrm{BC})$ measured with the aethalometer. On average the concentration of EC was only $78 \%$ of that of $\mathrm{BC}$. This difference is partially due to the

\section{AMTD}

$4,6577-6614,2011$

\section{Monitoring chemical composition of ambient aerosol particles}

H. Timonen et al.

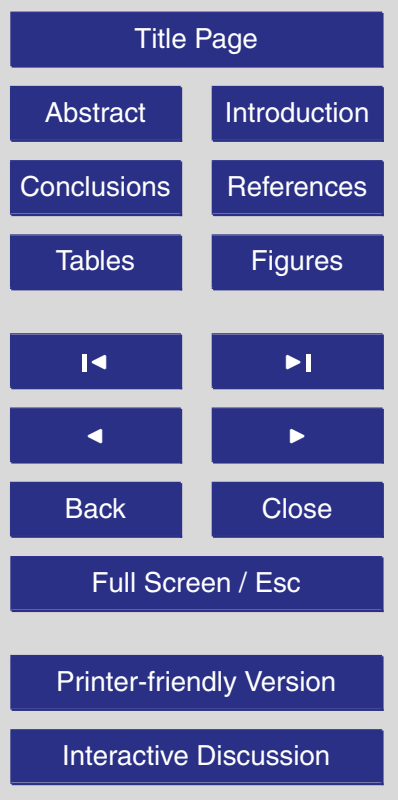


different cut-off sizes for the RT-OCEC and the aethalometer $(1 \mu \mathrm{m}$ and $2.5 \mu \mathrm{m}$, respectively) resulting in slightly different size fraction and possibly in different chemical composition of particles measured. Also the wavelength used was different being $660 \mathrm{~nm}$ for the RT-OCEC and $880 \mathrm{~nm}$ for the aethalometer. The mass absorption efficiency, 5 needed for calculations, was $16.6 \mathrm{~m}^{2} \mathrm{~g}^{-1}$ for the aethalometer whereas the calibration of RT-EC had been performed by the manufacturer. Despite all the differences in measurements, a good correlation $(r=0.97)$ was observed between the RT-OCEC and the aethalometer.

\subsection{Real-time mass closure}

10 Real-time mass closure was constructed by comparing the chemical components measured by online methods (PILS-IC and RT-OCEC) with the $\mathrm{PM}_{2.5}$ measured by the TEOM. Only the major ions (sulfate, nitrate and ammonium) were used to construct the mass closure. The RT-OCEC was measured with a timeresolution of three hours and therefore also the data from the PILS-IC and the TEOM were averaged to cor15 responding periods: 00:00-03:00, 03:00-06:00, 06:00-09:00, 09:00-12:00, 12:0015:00, 15:00-18:00, 18:00-21:00 and 21:00-24:00 at local time. Excluding the measurements, when one or more of the instruments was not running properly, the total number of data points was 1225. Similar to the filters, a multiplier equal to 1.6 was used to convert the measured organic carbon to particulate organic matter. Figure 5 20 represents a month long period when the mass closure was reached well. During February $2007,90 \%$ of the $\mathrm{PM}_{2.5}$ mass was identified by chemical analyses. During the year-long measurements, on average $65 \%$ of $\mathrm{PM}_{2.5}$ was identified by the chemical analyses. The difference between the analyzed and the measured mass was largest when the $\mathrm{PM}_{2.5}$ concentration was low. Especially for the $\mathrm{PM}_{2.5}$ concentra-

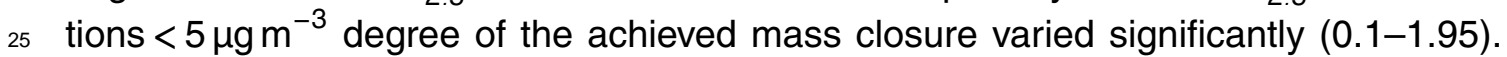
At that concentration level all the instruments were running close to their detection limits giving a high total uncertainty for the mass closure. When the concentrations were over $15 \mathrm{\mu g} \mathrm{m}^{-3}$, the mass closure was not larger than 1.2, but it could still be as low 6592
AMTD

$4,6577-6614,2011$

\section{Monitoring chemical composition of ambient aerosol particles}

H. Timonen et al.

\section{Title Page}


as 0.22 . For the largest concentrations $\left(>50 \mu \mathrm{gm}^{-3}\right)$ the mass closure was in range $0.85-1.0$, however, the number of data points was very limited $(N=4)$.

Chemical composition was investigated further by classifying 3-h measurements to five different classes according to their $\mathrm{PM}_{2.5}$ concentration $(0-5,5-10,10-20,20$ $530,>30 \mu \mathrm{g} \mathrm{m}^{-3}$ ) (Fig. 6). Going from the $\mathrm{PM}_{2.5}$ concentration below $5 \mu \mathrm{g} \mathrm{m}^{-3}$ to the concentration above $30 \mathrm{\mu g} \mathrm{m}^{-3}$ clear differences were found in the chemical composition. The contribution of EC was largest at the $\mathrm{PM}_{2.5}$ of $<5 \mu \mathrm{g} \mathrm{m}^{-3}$ and it decreased when $\mathrm{PM}_{2.5}$ concentration increased. The contribution of POM was approximately $47 \%$ when the $\mathrm{PM}_{2.5}$ concentration was below $20 \mathrm{\mu g} \mathrm{m}^{-3}$, but started to increase when 10 it was above that value. The contribution of $\mathrm{POM}$ was clearly largest when the $\mathrm{PM}_{2.5}$ concentration was above $30 \mathrm{\mu g} \mathrm{m}^{-3}$, however, all the large $\mathrm{PM}_{2.5}$ concentrations were measured during the biomass smoke episode in August, and therefore the source for all high concentrations was the same or at least similar. For sulfate, ammonium and nitrate the dependence on the concentration level was similar. The contribution of ions 15 was largest at the $\mathrm{PM}_{2.5}$ level of $0-20 \mu \mathrm{g} \mathrm{m}^{-3}$, whereas it was smallest when $\mathrm{PM}_{2.5}$ was larger than $30 \mathrm{\mu g} \mathrm{m}^{-3}$.

\subsection{Diurnal and seasonal trends}

The campaign-averaged diurnal trends for ions, POM and EC are presented in Fig. 7. Since the timeresolution for $\mathrm{EC}$ and $\mathrm{OC}$ was three hours, also the ion and $\mathrm{PM}_{2.5}$ mass concentrations were averaged to the corresponding time periods. No diurnal variation was found for POM, ammonium and sulfate. Diurnal variation was insignificant also for the semivolatile $\mathrm{PM}_{2.5}$ measured with the TEOM (Fig. 7). Most evident diurnal variation was observed for EC: it gained highest value in the morning at 6-9 and the lowest in the night at 3-6 (Fig. 7). Of the ions only nitrate had a diurnal trend with a been observed by Hennigan et al. (2008) and Poulain et al. (2011). Figure 8 represents the average diurnal cycles of nitrate (one-hour averages), temperature, global

AMTD

$4,6577-6614,2011$

\section{Monitoring chemical composition of ambient aerosol particles}

H. Timonen et al.

\section{Title Page}


radiation and relative humidity. It seems that the morning peak does not correlate with the meteorological parameters given, and is more likely caused by the increased traffic emissions during rush hour. The concentration of nitrate was lowest in the afternoon and in the evening. The lower concentrations in the afternoon were probably 5 caused by the increased mixing layer height. In the study of Järvi et al. (2008) in Helsinki it was found that also black carbon, which is non-volatile, quite systematically has lower concentrations during afternoon. Concurrently the ambient temperature is increasing, transferring particle-phase nitrate into the gas-phase, and that may also contribute slightly the nitrate concentrations. Also the difference between weekdays and the weekend was studied. Of all the chemical components only EC had a clear weekday-to-weekend variation (not shown). On weekdays EC concentrations started to raise at 6 a.m. simultaneously with the increasing traffic volumes. EC concentrations remained at high level until the evening rush hour was over at around 6 p.m. Minimum EC concentrations were observed at night time between 0-3. During weekends the 15 diurnal trend for EC was minimal.

To study the seasonal differences, one month was chosen to represent that particular season: February for winter, April for spring, June for summer and September for autumn. Seasonal differences during the measurement campaign were large. The largest ion, EC and OC concentrations were measured during winter, or during winter and spring for nitrate (Figs. 9, 10). The lowest concentrations for all compounds, except for OC, were measured in summer. Therefore, the average contribution of $\mathrm{OC}$ was largest in summer. The concentrations of potassium (not shown) were also highest in winter (excluding the forest fire episodes) and lowest in summer indicating that the local biomass burning for domestic heating was likely to elevate the aerosol concentrations sent long-range transported aerosol particles. The EC concentrations were $82 \pm 41 \%$ higher in winter than in summer, on average. The high EC concentrations in winter are likely caused by traffic emissions from nearby road or biomass burning for domestic heating, amplified by poorer atmospheric mixing in winter. The diurnal cycle of EC,
AMTD

$4,6577-6614,2011$

\section{Monitoring chemical composition of ambient aerosol particles}

H. Timonen et al.

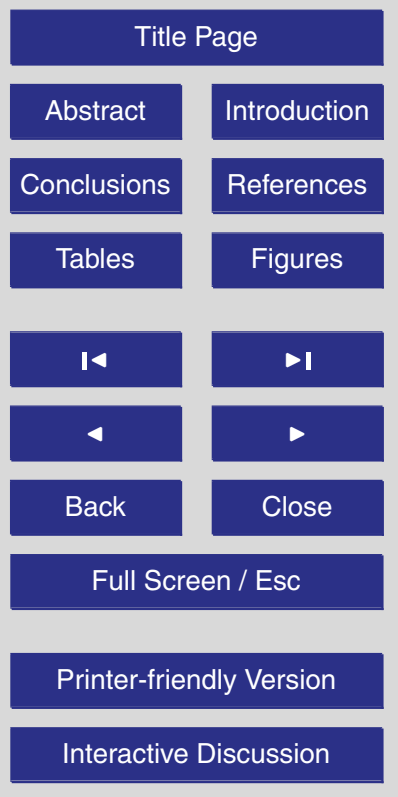


with maximum at weekdays during the rush hours, indicates that traffic is likely the major source of EC. However, EC had slightly different diurnal trends in different seasons. In summer and fall the concentrations of EC decreased sharply after the peak at 6-9 a.m. whereas in winter the concentrations stayed at higher level until the night 5 (Fig. 10a) probably because of the more stable boundary layer height during the day. For OC a diurnal trend was only found in summer (Fig. 10b). Similar to nitrate in fall (Fig. 9b) the concentrations of OC in summer had lowest values in the afternoon and early evening due to the efficient mixing of pollutants and transfer of particle-phase OC to gas-phase.

10 Nitrate had clear differences in both concentrations and diurnal cycles during different seasons (Fig. 9b). The peak in nitrate concentration in the morning is most pronounced when the nitrate concentrations are large in winter and spring. The decrease in the afternoon can be clearly seen in fall but in summer the nitrate concentrations have no diurnal changes. For ammonium no seasonal or diurnal trends were de15 tected, however, in summer slightly lower concentrations were observed in the evening (Fig. 9a).

\section{Conclusions}

High timeresolution measurements of major chemical components in fine particles were conducted at urban background station in Finland from February 2006 to Febru20 ary 2007. Long-term measurements provided important information about differences between results of different online methods (PILS-IC, RT-OCEC, TEOM) and the conventional filter measurements. Temporal changes, such as diurnal cycles and short pollution episodes were detected only with online methods. Volatility of measured compound was observed to have an effect to the results in PILS. The results of the PILS 25 agreed well with the results of the filter measurements for non-volatile species, such as sulfate and potassium. Larger discrepancies were observed for semivolatile nitrate

\section{AMTD}

$4,6577-6614,2011$

\section{Monitoring chemical composition of ambient aerosol particles}

H. Timonen et al.

\section{Title Page}

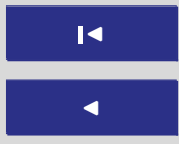

$>$ I

Back

$\checkmark$

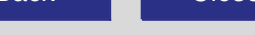

Full Screen / Esc

Printer-friendly Version

Interactive Discussion 
and ammonium. Sulfate measured from the filters was $18 \%$ higher than that from the PILS-IC whereas nitrate and ammonium were 9.1 and $41 \%$ lower when compared to the PILS results. Many species, like oxalate, sodium and chloride concentrations were most of the time too low and could not be quantified accurately. Larger potassium 5 and oxalate concentration were observed only during biomass burning episodes as could be expected. For EC and OC a strong correlation was observed between filter $\left(\mathrm{PM}_{1}\right)$ and online measurements (RT-OCEC). For OC the concentrations measured with RT-OCEC were on average $10 \%$ higher than the concentrations measured from filter samples.

10 High timeresolution measurements provided important information about the diurnal trends. Nitrate was observed to peak in early morning, during the rush hours. The peak in nitrate concentration in the morning was most pronounced when the concentrations were large in winter and spring. The decrease in the afternoon could be clearly seen in fall but in summer the nitrate concentrations had no diurnal changes. Also EC had 15 a clear diurnal cycle, with maximum during the morning rush hour. A real time mass closure was constructed by comparing the results from the TEOM with those from the PILS-IC and RT-OCEC. The analyzed compounds $\left(\mathrm{PM}_{1}\right.$; ions, POM, EC) represented on average $60 \%$ of $\mathrm{PM}_{2.5}$ mass. The difference in cutoff sizes $\left(\mathrm{PM}_{1}\right.$ and $\left.\mathrm{PM}_{2.5}\right)$ explained on average $25 \%$ of the unexplained mass whereas the volatilized mass fraction explained the remaining unexplained mass (18\%).

Acknowledgements. Financial support from the Graduate School in Physics, Chemistry, Biology and Meteorology of Atmospheric Composition and Climate Change (University of Helsinki) and European Union (EUCAARI, Contract No: 036833-2) is gratefully acknowledged. The research was also supported by the Academy of Finland Center of Excellence program (project 25 number 1118615).
AMTD

4, 6577-6614, 2011

\section{Monitoring chemical composition of ambient aerosol particles}

H. Timonen et al.

\section{Title Page}

Abstract Introduction

Conclusions References

Tables Figures
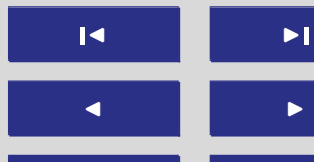

Back Close

Printer-friendly Version

Interactive Discussion 


\section{References}

Allen, G., Sioutas, C., Koutrakis, P., Reiss, R., Lurmann, F. W., and Roberts, P. T.: Evaluation of the TEOM® method for measurement of ambient particulate mass in urban areas, J. Air \& Waste Manage. Assoc., 14, 682-689, 1997.

5 Allan, J. D., Jimenez, J. L., Williams, P. I., Alfarra, M. R., Bower, K. N., Jayne, J. T., Coe, H., and Worsnop, D. R.: Quantitative sampling using an Aerodyne aerosol mass spectrometer, 1, Techniques of data interpretation and error analysis, J. Geophys. Res., 108, 4090. doi:10.1029/2002JD002358, 2003.

Arhami, M., Kuhn, T., Fine, P. M., Delfino, R. J., and Sioutas, C.: Effects of Sampling Artifacts and Operating Parameters on the Performance of a Semicontinuous Particulate Elemental Carbon/Organic Carbon Monitor, Environ. Sci. Technol., 40, 945-954, 2006.

Bae, M., Schwab, J. J., Zhang, Q., Hogrefe, O., Demerjian, K. L., Weimer, S., Rhoads, K., Orsini, D., Venkatachari, P., and Hopke, P. K.: Interference of organic signals in highly time resolved nitrate measurements by low mass resolution aerosol mass spectrometry, J. Geo-

15 phys. Res., 112, D22305, doi:10.1029/2007JD008614, 2007.

Berner, A. and Lürzer, C.: Mass size distributions of traffic aerosols at Vienna, J. Phys. Chem., 84, 2079-2083, 1980.

Brunekreef, B. and Holgate, S. T.: Air pollution and health, Lancet, 360, 1233-1242, 2002.

Dunlea, E. J., DeCarlo, P. F., Aiken, A. C., Kimmel, J. R., Peltier, R. E., Weber, R. J., Tomlinson, J., Collins, D. R., Shinozuka, Y., McNaughton, C. S., Howell, S. G., Clarke, A. D., Emmons, L. K., Apel, E. C., Pfister, G. G., van Donkelaar, A., Martin, R. V., Millet, D. B., Heald, C. L., and Jimenez, J. L.: Evolution of Asian aerosols during transpacific transport in INTEX-B, Atmos. Chem. Phys., 9, 7257-7287, doi:10.5194/acp-9-7257-2009, 2009.

Grover, B. D., Eatough, N. L., Eatough, D. J., Chow, J. C., Watson, J. G., Ambs, J. L., Meyer, M. B., Hopke, P. K., Al-Horr, R., Later, D. W., and Wilson, W. E.: Measurement of Both Nonvolatile and Semi-Volatile Fractions of Fine Particulate Matter in Fresno, CA, Aerosol Sci. Technol., 40, 811-826, 2006.

Hansen, A. D. A., Rosen, H., and Novakov, T.: The aethalometer: an instrument for the realtime measurement of optical absorption by aerosol particles, Sci. Total Environ., 36, 191196, 1984.

Hennigan, C. J., Sullivan, A. P., Fountoukis, C. I., Nenes, A., Hecobian, A., Vargas, O., Peltier, R. E., Case Hanks, A. T., Huey, L. G., Lefer, B. L., Russell, A. G., and Weber, R. J.: On

\section{Monitoring chemical composition of ambient aerosol particles}

H. Timonen et al.

\section{Title Page}

Abstract Introduction

Conclusions References

Tables Figures

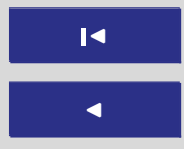
$>1$

Back

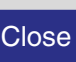

Full Screen / Esc

Printer-friendly Version

Interactive Discussion 
the volatility and production mechanisms of newly formed nitrate and water soluble organic aerosol in Mexico City, Atmos. Chem. Phys., 8, 3761-3768, doi:10.5194/acp-8-3761-2008, 2008.

Hering, S. and Cass, G.: The magnitude of Bias in the measurement of $\mathrm{PM}_{2.5}$ arising from 5 volatilization of particulate nitrate from Teflon filters, J. Air \& Waste Manage. Assoc., 49, 725-733, 1999.

Jacobson, M. C., Hansson, H.-C., Noone, K. L., and Charlson, R. J.: Organic atmospheric aerosols: Review and state of the science, Rev. Geophys., 38, 267-294, 2000.

Järvi, L., Junninen, H., Karppinen, A., Hillamo, R., Virkkula, A., Mäkelä, T., Pakkanen, T., and Kulmala, M.: Temporal variations in black carbon concentrations with different time scales in Helsinki during 1996-2005, Atmos. Chem. Phys., 8, 1017-1027, doi:10.5194/acp-8-10172008, 2008.

Järvi, L., Hannuniemi, H., Hussein, T., Junninen, H., Aalto, P. P., Hillamo, R., Mäkelä, T., Keronen, P., Siivola, E., Vesala, T., and Kulmala, M.: The urban measurement station SMEAR III: Continuous monitoring of air pollution and surface-atmosphere interactions in Helsinki, Finland, Boreal Env. Res., 14 (suppl. A), 86-109, 2009.

Karppinen, A., Härkönen, J., Kukkonen, J., Aarnio, P., and Koskentalo, T.: Statistical model for assessing the portion of fine particulate matter transported regionally and long range to urban air, Scand J. Work Environ. Health., 30 (Suppl 2), 47-53, 2004.

Kondo, Y., Miyazaki, Y., Takegawa, N., Miyakawa, T., Weber, R. J., Jimenez, J. L., Zhang, Q., and Worsnop, D. R.: Oxygenated and water-soluble organic aerosols in Tokyo, J. Geophys. Res., 112, D011203, doi:10.1029/2006JD007056, 2007.

Kuokka, S., Teinilä, K., Saarnio, K., Aurela, M., Sillanpää, M., Hillamo, R., Kerminen, V.-M., Pyy, K., Vartiainen, E., Kulmala, M., Skorokhod, A. I., Elansky, N. F., and Belikov, I. B.: Using a moving measurement platform for determining the chemical composition of atmospheric aerosols between Moscow and Vladivostok, Atmos. Chem. Phys., 7, 4793-4805, doi:10.5194/acp-7-4793-2007, 2007.

Laakso, L., Hussein, T., Aarnio, P., Komppula, M., Hiltunen, V., Viisanen, Y., and Kulmala, M.: Diurnal and annual characteristics of particle mass and number concentrations in urban, 30 rural and Arctic environments in Finland, Atmos. Environ., 37, 2629-2641, 2003.

Loo, B. W. and Cork, C. P.: Development of high efficiency virtual impactor, Aerosol Sci. Technol., 9, 167-170, 1988.

Ma, Y., Weber, R. J., Maxwell-Meier, K., Orsini, D. A., Lee, Y.-N., Huebert, B. J., Howell, S.
AMTD

$4,6577-6614,2011$

\section{Monitoring chemical composition of ambient aerosol particles}

H. Timonen et al.

\section{Title Page}

Abstract Introduction

Conclusions References

Tables Figures

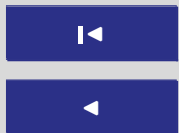

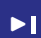

Back Close 
G., Bertram, T., Talbot, R. W., Dibb, J. E., and Scheuer, E.: Intercomparisons of airborne measurements of aerosol ionic chemical composition during TRACE-P and ACE-Asia, J. Geophys. Res., 109, D15S06, doi:10.1029/2003JD003673, 2004.

Marple, V. A., Rubow, K. L., and Behm, S. M.: A Microorifice Uniform Deposit Impactor 5 (MOUDI): Description, calibration and use, Aerosol Sci. Technol., 14, 434-446, 1991.

Niemi, J. V., Tervahattu, H., Vehkamäki, H., Kulmala, M., Koskentalo, T., Sillanpää, M., and Rantamäki, M.: Characterization and source identification of a fine particle episode in Finland, Atmos. Environ., 38, 5003-5012, 2004.

Orsini, D. A., Ma, Y., Sullivan, A., Sierau, B., Baumann, K., and Weber, R. J.: Refinements to the particle-into-liquid sampler (PILS) for ground and airborne measurements of water soluble aerosol composition, Atmos. Environ., 37, 1243-1259, 2003.

Pakkanen, T. A., Loukkola, K., Korhonen, C. H., Aurela, M., Mäkelä, T., Hillamo, R., Aarnio, P., Koskentalo, T., Kousa, A., and Maenhaut, W.: Sources and chemical composition of atmospheric fine and coarse particles in the Helsinki area, Atmos. Environ., 35, 5381-5391, 2001.

Parshintsev, J., Räsänen, R., Hartonen, K., Kulmala, M., and Riekkola, M.-L.: Analysis of organic compounds in ambient aerosols collected with the particle-into-liquid sampler, Boreal Env. Res., 14, 630-640, 2009.

Patashnick, H. and Rupprecht, E. G.: Continuous PM-10 measurements using the Tapered 20 Element Oscillating MicroBalance, J. Air \& Waste Manage. Assoc., 41, 1079-1083, 1991.

Pathak, R. K. and Chan, C. K.: Inter-particle and gas-particle interactions in sampling artifacts of $\mathrm{PM}_{2.5}$ in filter-based samplers, Atmos. Environ., 39, 1597-1607, 2005.

Pope, C. A. and Dockery, D. W.: Health Effects of Fine Particulate Air Pollution: Lines that Connect, J. Air \& Waste Manage. Assoc., 56, 709-742, 2006.

Poulain, L., Spindler, G., Birmili, W., Plass-Dülmer, C., Wiedensohler, A., and Herrmann, $\mathrm{H}$.: Seasonal and diurnal variations of particulate nitrate and organic matter in the Central European atmospheric aerosol, Atmos. Chem. Phys. Discuss., 11, 11611-11647, doi:10.5194/acpd-11-11611-2011, 2011.

Saarikoski, S., Sillanpää, M., Sofiev, M., Timonen, H., Saarnio, K., Teinilä, K., Karppinen, A., Kukkonen, J., and Hillamo, R.: Chemical composition of aerosols during a major biomass burning episode over northern Europe in spring 2006: Experimental and modeling assessments, Atmos. Environ., 41, 3577-3589, 2007.

Saarikoski, S., Timonen, H., Saarnio, K., Aurela, M., Järvi, L., Keronen, P., Kerminen, V.-M.,

\section{AMTD}

4, 6577-6614, 2011

\section{Monitoring chemical composition of ambient aerosol particles}

H. Timonen et al.

\section{Title Page}

Abstract Introduction

Conclusions References

Tables Figures

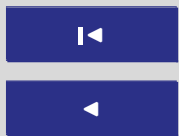
$\Delta$

Back Close Full Screen / Esc

Printer-friendly Version

Interactive Discussion 
and Hillamo, R.: Sources of organic carbon in fine particulate matter in northern European urban air, Atmos. Chem. Phys., 8, 6281-6295, doi:10.5194/acp-8-6281-2008, 2008.

Saarnio, K., Aurela, M., Timonen, H., Saarikoski, S., Teinilä, K., Mäkelä, T., Sofiev, M., Koskinen, J., Aalto, P. P., Kulmala, M., Kukkonen, J., and Hillamo, R.: Chemical composition of fine particles in fresh smoke plumes from boreal wild-land fires in Europe, Sci. Total Environ., 408, 2527-2542, 2010.

Sciare, J., d'Argouges, O., Zhang, Q. J., Sarda-Estève, R., Gaimoz, C., Gros, V., Beekmann, M., and Sanchez, O.: Comparison between simulated and observed chemical composition of fine aerosols in Paris (France) during springtime: contribution of regional versus continental emissions, Atmos. Chem. Phys., 10, 11987-12004, doi:10.5194/acp-10-11987-2010, 2010.

Seinfeld, J. and Pandis, S.: Atmospheric chemistry and physics, John Wiley \& Sons, New York, 1998.

Sillanpää, M., Saarikoski, S., Hillamo, R., Pennanen, A., Makkonen, U., Spolnik, Z., Van Grieken, R., Koskentalo, T., and Salonen, R. O.: Chemical composition, mass size distribution and source analysis of long-range transported wildfire smokes in Helsinki, Sci. Total Environ., 350, 119-135, 2005.

Sorooshian, A., Brechtel, F. J., Ma, Y., Weber, R. J., Corless, A., Flagan, R. C., and Seinfeld, J. H.: Modeling and Characterization of a Particle-into-Liquid Sampler (PILS), Aerosol. Sci. Technol., 40, 396-409, 2006.

Sorooshian, A., Ng, N. L., Chan, A. W. H., Feingold, G., Flagan, R. C., and Seinfeld, J. H.: Particulate organic acids and overall water-soluble aerosol composition measurements from the 2006 Gulf of Mexico Atmospheric Composition and Climate Study (GoMACCS), J. Geophys. Res., 112, D13201, doi:10.1029/2007JD008537, 2007.

Timonen, H., Saarikoski, S., Tolonen-Kivimäki, O., Aurela, M., Saarnio, K., Petäjä, T., Aalto, P. P., Kulmala, M., Pakkanen, T., and Hillamo, R.: Size distributions, sources and source areas of water-soluble organic carbon in urban background air, Atmos. Chem. Phys., 8, 5635-5647, doi:10.5194/acp-8-5635-2008, 2008.

Timonen, H., Aurela, M., Carbone, S., Saarnio, K., Saarikoski, S., Mäkelä, T., Kulmala, M., Kerminen, V.-M., Worsnop, D. R., and Hillamo, R.: High time-resolution chemical characterization of the water-soluble fraction of ambient aerosols with PILS-TOC-IC and AMS, Atmos. Meas. Tech., 3, 1063-1074, doi:10.5194/amt-3-1063-2010, 2010.

Turpin, B. J. and Lim, H.-J.: Species Contributions to $\mathrm{PM}_{2.5}$ Mass Concentrations: Revisiting Common Assumptions for Estimating Organic Mass, Aerosol Sci. Tech., 35, 602-610, 2001.
AMTD

4, 6577-6614, 2011

\section{Monitoring chemical composition of ambient aerosol particles}

H. Timonen et al.

\section{Title Page}

Abstract Introduction

Conclusions

Tables References Figures

14 $\Delta$

\section{4}

Back

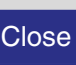

Full Screen / Esc

Printer-friendly Version

Interactive Discussion 
Viana, M., Chi, X., Maenhaut, W., Cafmeyer, J., Querol, X., Alastuey, A., Mikuška, P., and Večeřa, Z.: Influence of Sampling Artefacts on Measured PM, OC, and EC Levels in Carbonaceous Aerosols in an Urban Area, Aerosol. Sci. Technol., 40, 107-117, 2006.

Viidanoja, J., Sillanpää, M. Laakia, J., Kerminen, V.-M., Hillamo, R., Aarnio, P. and Koskentalo, $5 \quad$ T.: Organic and black carbon in $\mathrm{PM}_{2.5}$ and $\mathrm{PM}_{10}$ : 1 year data from urban site in Helsinki, Finland, Atmos. Environ., 26, 3183-3193, 2002.

Weber, R. J., Orsini, D., Daun, Y., Lee, Y.-N., Klotz, P. J., and Brechtel, F.: A Particle intoLiquid Collector for Rapid Measurement of Aerosol Bulk Chemical Composition, Aerosol. Sci. Technol., 35, 718-727, 2001.

10 Wilson, W. E., Grover, B. D., Long, R. W., Eatough, N. L., and Eatough, D. J.: The Measurement of Fine Particulate Semivolatile Material in Urban Aerosols, J. Air \& Waste Manage. Assoc., 56, 384-397, 2006.

\section{AMTD}

$4,6577-6614,2011$

\section{Monitoring chemical composition of ambient aerosol particles}

H. Timonen et al.

\section{Title Page}

Abstract Introduction

Conclusions

References

Tables

Figures

14

4

Back

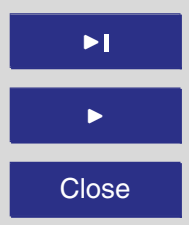

Full Screen / Esc

Printer-friendly Version

Interactive Discussion 


\section{AMTD}

4, 6577-6614, 2011

\section{Monitoring chemical composition of ambient aerosol particles} ous/semicontinuous instruments. Ions were measured with the PILS-IC system, OC and EC with the RT-OCEC, and BC with the aethalometer. $N$ represents the number of samples available for the comparison.

\begin{tabular}{llrr}
\hline Component & Particle size & Filter/online -ratio & $N$ \\
\hline $\mathrm{SO}_{4}^{2-}\left(\mathrm{PM}_{1}\right.$ vs. PILS-IC) & $<1 \mu \mathrm{m}$ & $1.18 \pm 0.28$ & 214 \\
$\mathrm{NO}_{3}^{-}\left(\mathrm{PM}_{1}\right.$ vs. PILS-IC) & $<1 \mu \mathrm{m}$ & $0.59 \pm 0.66$ & 187 \\
$\mathrm{NH}_{4}^{+}\left(\mathrm{PM}_{1}\right.$ vs. PILS-IC) & $<1 \mu \mathrm{m}$ & $0.91 \pm 0.32$ & 212 \\
$\mathrm{OC}\left(\mathrm{PM}_{1}\right.$ vs. RT-OCEC) & $<1 \mu \mathrm{m}$ & $0.90 \pm 0.22$ & 165 \\
$\mathrm{EC}\left(\mathrm{PM}_{1}\right.$ vs. RT-OCEC) & $<1 \mu \mathrm{m}$ & $0.89 \pm 0.21$ & 167 \\
$\mathrm{EC}_{\text {vs. }} \mathrm{BC}^{\mathrm{b}}(\mathrm{RT}-\mathrm{OCEC}$ vs. Aethalometer $)$ & $<1^{\mathrm{c}} / 2.5 \mu \mathrm{m}^{\mathrm{d}}$ & $0.78 \pm 0.33$ & 1127 \\
\hline
\end{tabular}

a The sum of $\mathrm{PM}_{2.5}$ and the mass volatilized from the TEOM.

b 3-h average.

${ }^{\mathrm{c}} \mathrm{EC}$.

${ }^{d}$ BC.

\section{H. Timonen et al.}

\section{Title Page}

Abstract

Conclusions

Tables

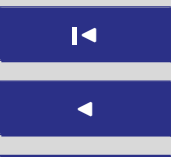

Back

\section{Introduction}

References

Figures

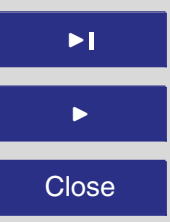

Full Screen / Esc

Printer-friendly Version

Interactive Discussion 


\section{AMTD}

4, 6577-6614, 2011

\section{Monitoring chemical composition of ambient aerosol particles}

Table 2. Online measurements during the intensive measurement campaign from February 2006 to February 2007.

\begin{tabular}{llllll}
\hline $\begin{array}{l}\text { Component/ } \\
\text { property }\end{array}$ & Instrument & $\begin{array}{l}\text { Cutoff } \\
\text { size }(\mu \mathrm{m})\end{array}$ & Measurement period & $\begin{array}{l}\text { Average } \pm \text { stdev } \\
\left(\mu \mathrm{g} \mathrm{m}^{-3}\right)\end{array}$ & $\begin{array}{l}\text { Maximum } \\
\left(\mu \mathrm{g} \mathrm{m}^{-3}\right)\end{array}$ \\
\hline Total mass & TEOM & 2.5 & $9.2 .2006-28.2 .2007$ & $13.8 \pm 11.4$ & 178.8 \\
OC, EC & RT-OCEC & 1 & $17.6 .2006-28.2 .2007$ & OC: $2.0 \pm 2.5$ & $\begin{array}{l}\text { OC: } 41 \\
\text { EC: } 0.74 \pm 0.64\end{array}$ \\
& & & & EC: 7.1 \\
\hline & & & & $\mathrm{NH}_{4}^{+}: 0.85 \pm 0.81$ & $\mathrm{NH}_{4}^{+}: 10$ \\
Major lons & PILS & 1 & $9.2 .2006-28.2 .2007^{\mathrm{a}}$ & $\begin{array}{l}\mathrm{NO}_{3}^{-}: 0.77 \pm 1.0 \\
\mathrm{SO}_{4}^{2-}: 1.7 \pm 1.8\end{array}$ & $\begin{array}{l}\mathrm{NO}_{3}^{-2}: 15 \\
\end{array}$ \\
& & & & $\mathrm{KO}_{4}^{2-}: 0.10 \pm 0.07$ & $\mathrm{~K}^{+}: 2.7$ \\
\hline BC & Aethalometer & 1 & $3.7 .-27.12 .2006$ & $1.0 \pm 0.8$ & 5.7 \\
\hline
\end{tabular}

H. Timonen et al.

a Due to technical problems, a break in PILS data from 28 November 2006 to 26 January 2007.

Title Page

Abstract

Introduction

Conclusions

References

Tables

Figures

14

4

Back

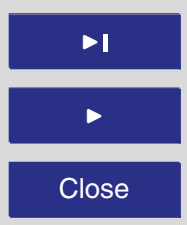

Full Screen / Esc

Printer-friendly Version

Interactive Discussion 


\section{AMTD}

4, 6577-6614, 2011

\section{Monitoring chemical composition of ambient aerosol particles}

Table 3. The measured mean and maximum values for each chemical species during the intensive measurement campaign from 9 February 2006 to 28 February 2007.

\begin{tabular}{|c|c|c|c|c|}
\hline & Component/property & Analytical instrument & $\begin{array}{l}\text { Average } \pm \text { stdev } \\
\left(\mu \mathrm{g} \mathrm{m}^{-3}\right)\end{array}$ & $\begin{array}{l}\text { Maximum } \\
\left(\mu \mathrm{g} \mathrm{m}^{-3}\right)\end{array}$ \\
\hline $\mathrm{PM}_{1}$ & $\mathrm{OC}, \mathrm{EC}$ & $\begin{array}{l}\text { Sunset OCEC aerosol } \\
\text { carbon analyzer }\end{array}$ & $\begin{array}{l}\text { OC: } 2.5 \pm 2.7 \\
\text { EC: } 0.91 \pm 0.71\end{array}$ & $\begin{array}{l}\text { OC: } 16 \\
\text { EC: } 7.1\end{array}$ \\
\hline $\mathrm{PM}_{1}$ & WSOC & Shimadzu TOC- $\mathrm{V}_{\mathrm{CPH}}$ & WSOC: $1.5 \pm 1.7$ & 10.65 \\
\hline $\mathrm{PM}_{1}$ & Major lons & Dionex ICS-2000 & $\begin{array}{l}\mathrm{NH}_{4}^{+}: 0.71 \pm 0.62 \\
\mathrm{NO}_{3}^{-}: 0.36 \pm 0.55 \\
\mathrm{SO}_{4}^{2-}: 1.8 \pm 1.4 \\
\mathrm{~K}^{+}: 0.07 \pm 0.16 \\
\text { Oxalate: } 0.09 \pm 0.09 \\
\mathrm{MSA}_{0} 0.03 \pm 0.05 \\
\mathrm{Cl}^{-}: 0.01 \pm 0.05\end{array}$ & $\begin{array}{l}\mathrm{NH}_{4}^{+}: 3.6 \\
\mathrm{NO}_{3}^{-}: 3.8 \\
\mathrm{SO}_{4}^{2-}: 7.4 \\
\mathrm{~K}^{+}: 2.5 \\
\text { Oxalate: } 0.56 \\
\mathrm{MSA}: 0.31 \\
\mathrm{Cl}^{-}: 0.5\end{array}$ \\
\hline $\begin{array}{l}\mathrm{PM}_{1} \\
\text { MOUDI }\end{array}$ & $\begin{array}{l}\text { Total mass } \\
=1.6^{\star} \mathrm{OC}+\mathrm{EC}+\text { ions } \\
\text { Total Mass, lons }\end{array}$ & $\begin{array}{l}\text { Calculated } \\
\text { Mettler M3 microbalance, } \\
\text { Dionex ICS-2000 }\end{array}$ & $7.8 \pm 6.5$ & 30 \\
\hline
\end{tabular}

\section{H. Timonen et al.}

\section{Title Page}

Abstract

Conclusions

Tables

14

4

Back

Full Screen / Esc

Printer-friendly Version

Interactive Discussion 


\section{AMTD}

\section{$4,6577-6614,2011$}

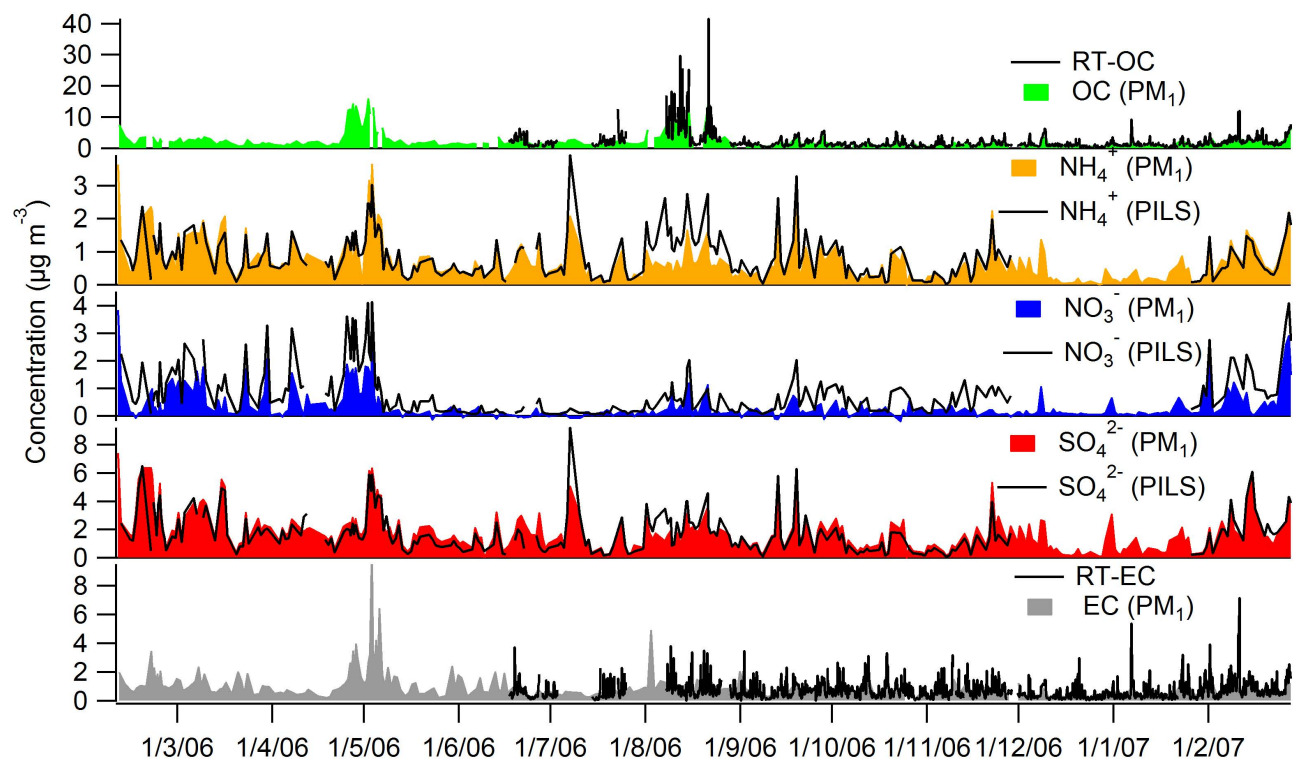

\section{Monitoring chemical composition of ambient aerosol particles}

H. Timonen et al.

\section{Title Page}

Fig. 1. The comparison between online and $\mathrm{PM}_{1}$ filter measurements for $\mathrm{OC}$, ammonium, nitrate, sulfate and EC. Sampling time for the $\mathrm{PM}_{1}$ filters was approximately $24 \mathrm{~h}$ during weekdays and $72 \mathrm{~h}$ on weekends and the ion results of the online instruments were averaged to corresponding time periods.

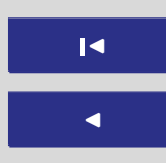

Back

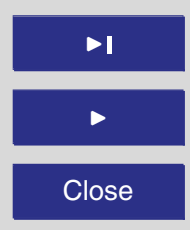

Full Screen / Esc

Printer-friendly Version

Interactive Discussion 


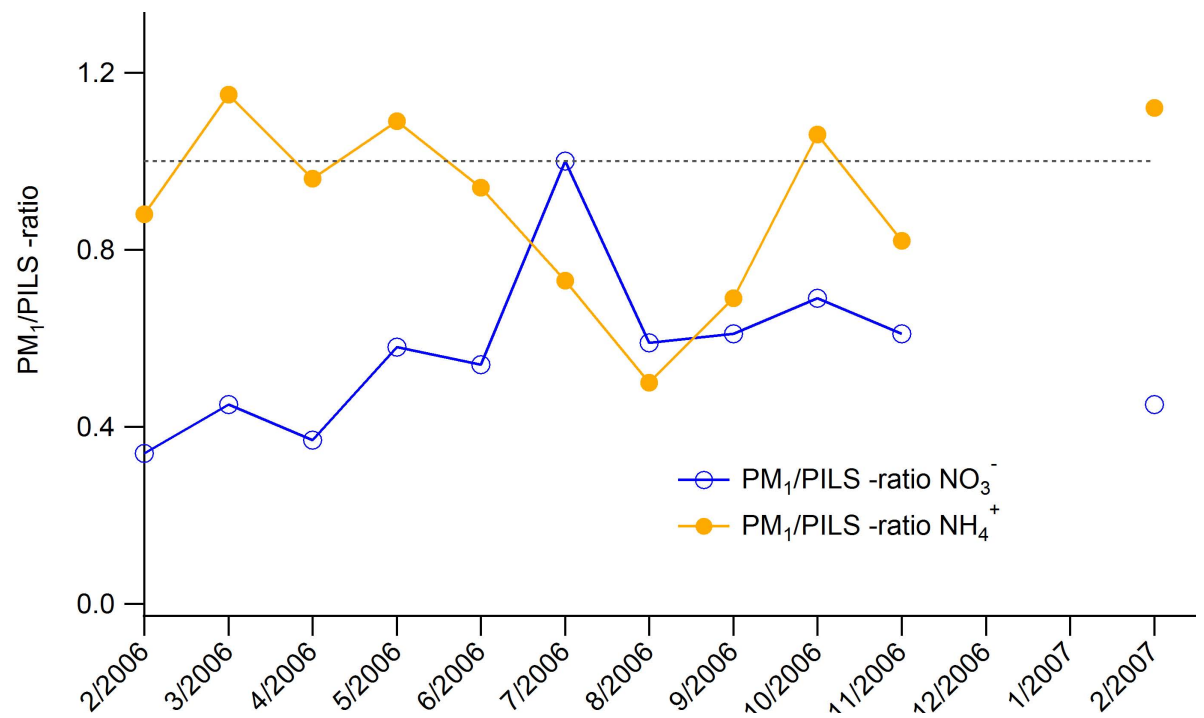

Fig. 2. The monthly average $\mathrm{PM}_{1} / \mathrm{PILS}$-ratios for ammonium and nitrate from 9 February 2006 to 28 February 2007.

\section{AMTD}

$4,6577-6614,2011$

\section{Monitoring chemical composition of ambient aerosol particles}

H. Timonen et al.

\section{Title Page}

Abstract Introduction

Conclusions

References

Tables

Figures

14

4

Back

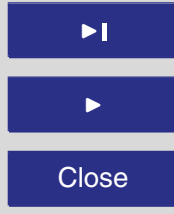

Full Screen / Esc

Printer-friendly Version

Interactive Discussion 


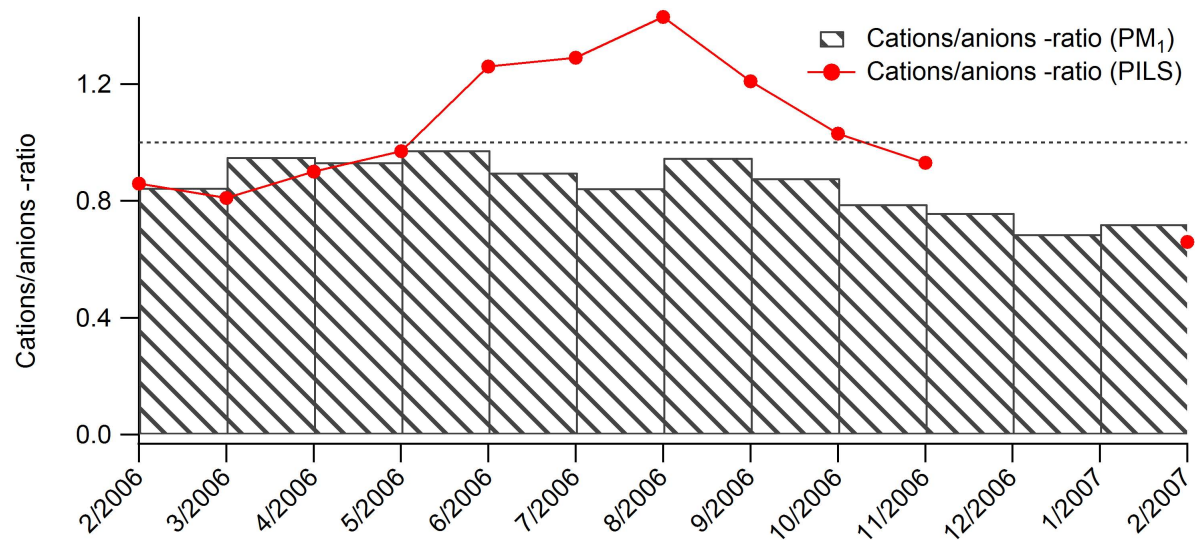

Fig. 3. The monthly average cations/anions -ratios based on the PILS and $\mathrm{PM}_{1}$ filter measurements.

\section{AMTD}

$4,6577-6614,2011$

Monitoring chemical composition of ambient aerosol particles

H. Timonen et al.

\section{Title Page}

Abstract Introduction

Conclusions

References

Tables

Figures
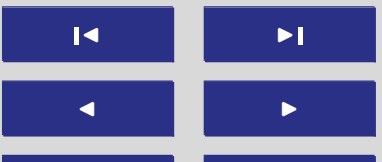

Back

Close

Full Screen / Esc

Printer-friendly Version

Interactive Discussion 


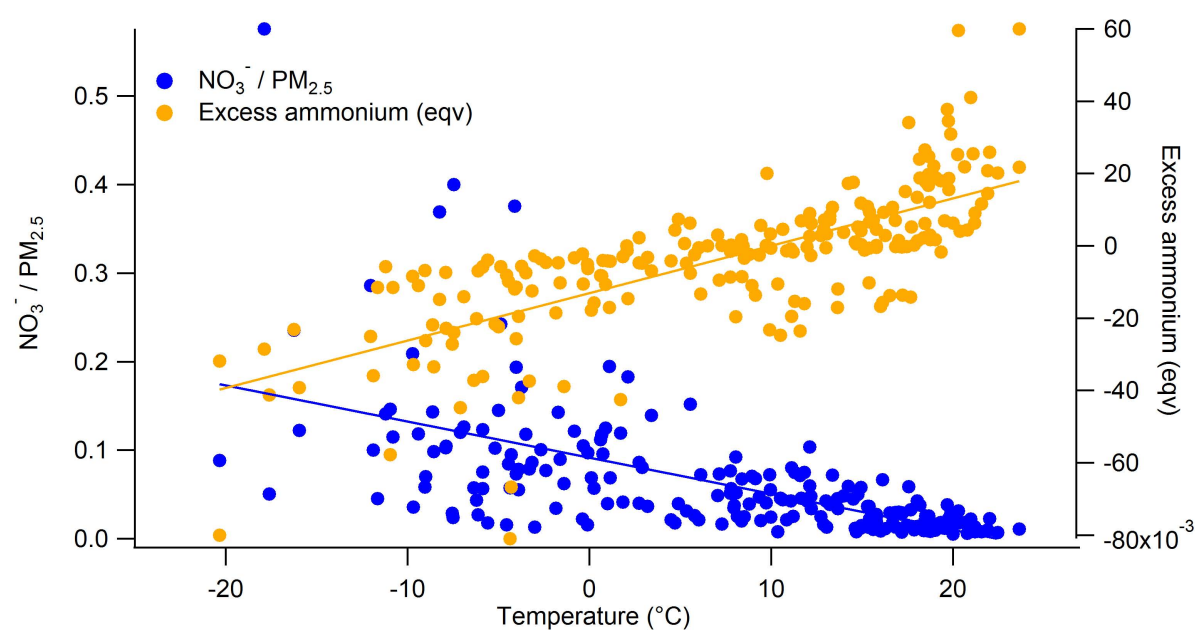

Fig. 4. The nitrate/PM $\mathrm{PM}_{2.5}$-ratio and amount of excess ammonium (eqv) as a function of temperature.

\section{AMTD}

$4,6577-6614,2011$

Monitoring chemical composition of ambient aerosol particles

H. Timonen et al.

\section{Title Page}

Abstract Introduction

Conclusions

References

Tables

Figures

14

4

Back

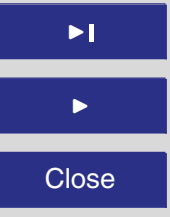

Full Screen / Esc

Printer-friendly Version

Interactive Discussion 


\section{AMTD}

4, 6577-6614, 2011

\section{Monitoring chemical composition of ambient aerosol particles}

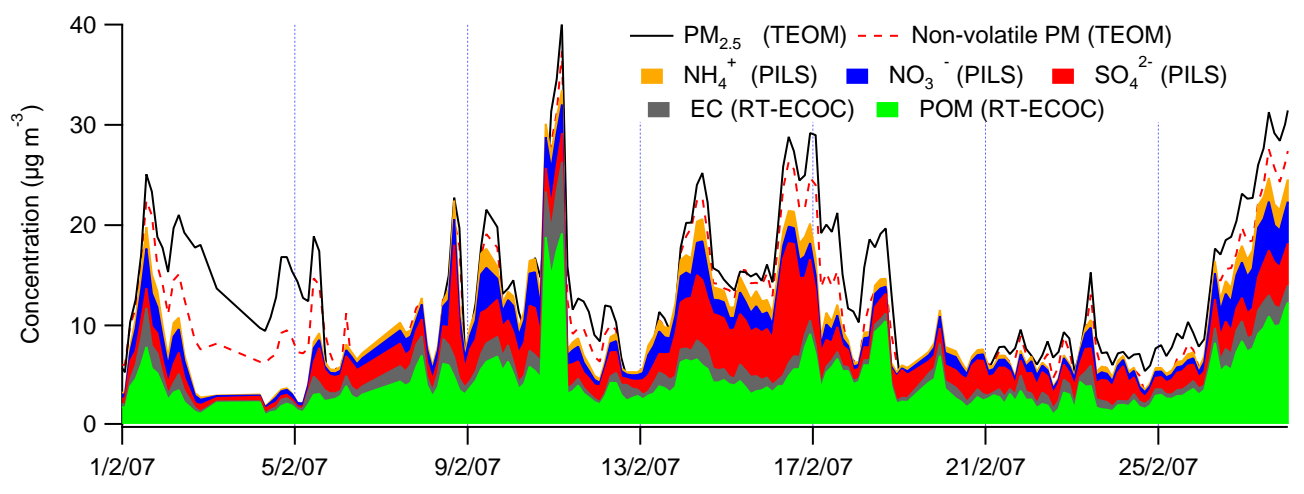

H. Timonen et al.

Fig. 5. The timeseries of major ions (sulphate,nitrate and ammonium), particulate organic matter (POM), inorganic carbon and $\mathrm{PM}_{2.5}$ and non-volatile PM (TEOM) mass concentration during February 2007.

\section{Title Page}

Abstract Introduction

Conclusions

References

Tables

Figures

14

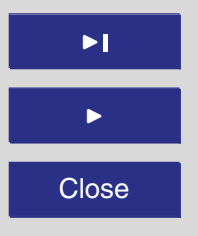

Back

lose

Full Screen / Esc

Printer-friendly Version

Interactive Discussion 


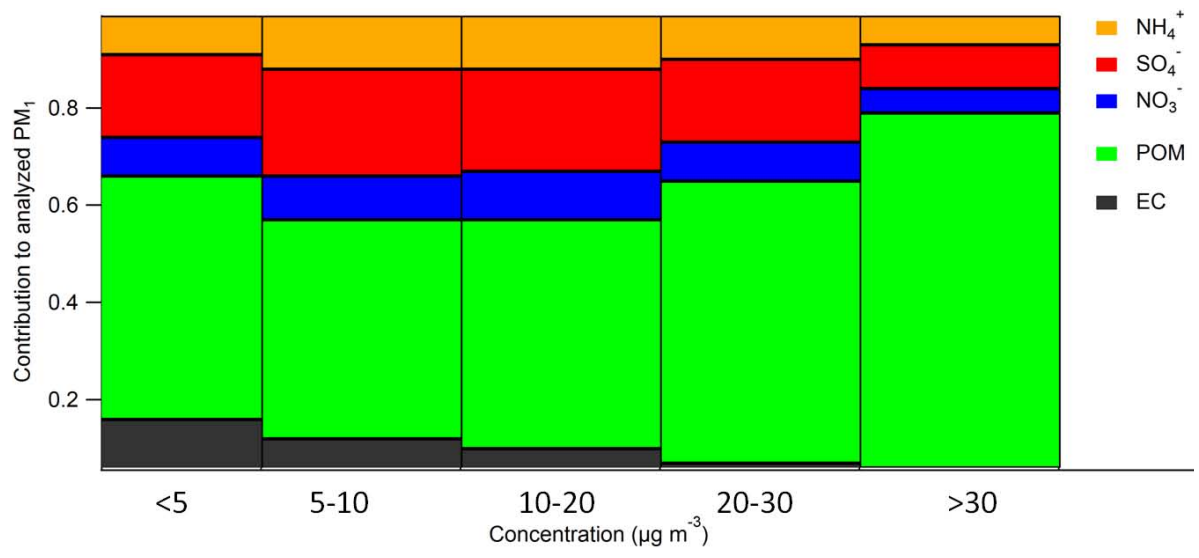

Fig. 6. The relative contribution of ions, $P O M$ and $E C$ to analyzed $\mathrm{PM}_{1}$ at different concentration levels.
AMTD

$4,6577-6614,2011$

Monitoring chemical composition of ambient aerosol particles

H. Timonen et al.

\section{Title Page}

Abstract

Introduction

Conclusions

References

Tables

Figures

14

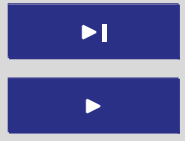

Back

Close

Full Screen / Esc

Printer-friendly Version

Interactive Discussion 


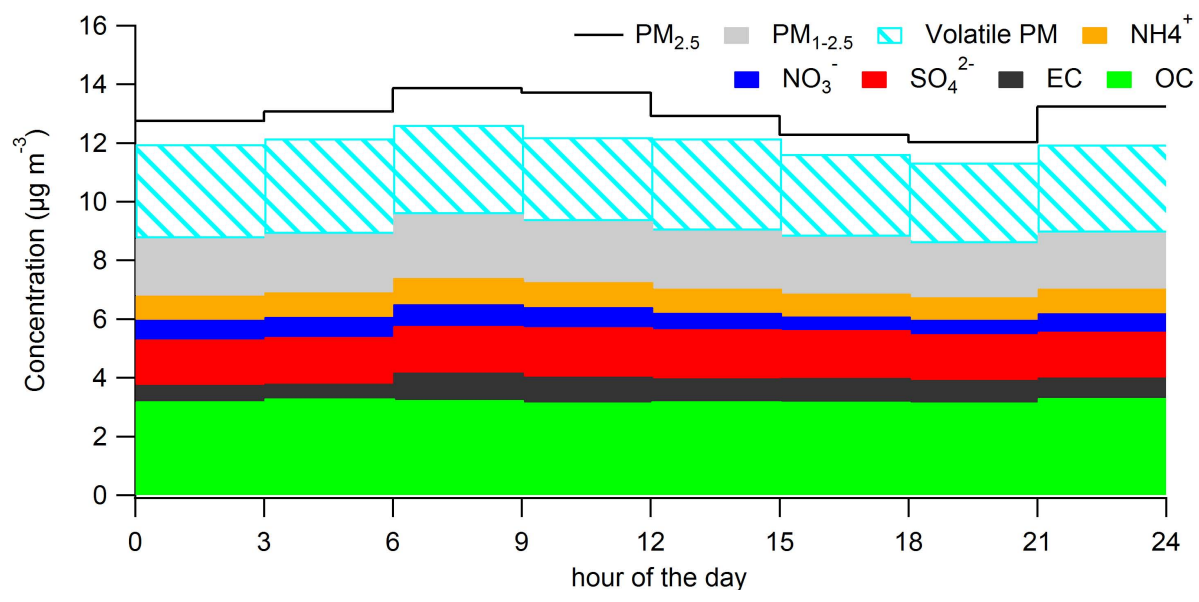

Fig. 7. The measured concentrations for major ions, $E C, P O M$ and $P M_{25}$ for three hour averages $(0-3,3-6,6-9,9-12,12-15,15-18,18-21,21-24)$. The amount of volatile PM is evaluated based on FDMS TEOM results and the mass between $\mathrm{PM}_{1}$ and $\mathrm{PM}_{2.5}$ is evaluated from simultaneous MOUDI collections.

\section{AMTD}

$4,6577-6614,2011$

\section{Monitoring chemical composition of ambient aerosol particles}

H. Timonen et al.

\section{Title Page}

Abstract

Conclusions

Tables

14

4

Back

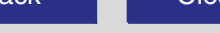

Full Screen / Esc

Printer-friendly Version

Interactive Discussion 


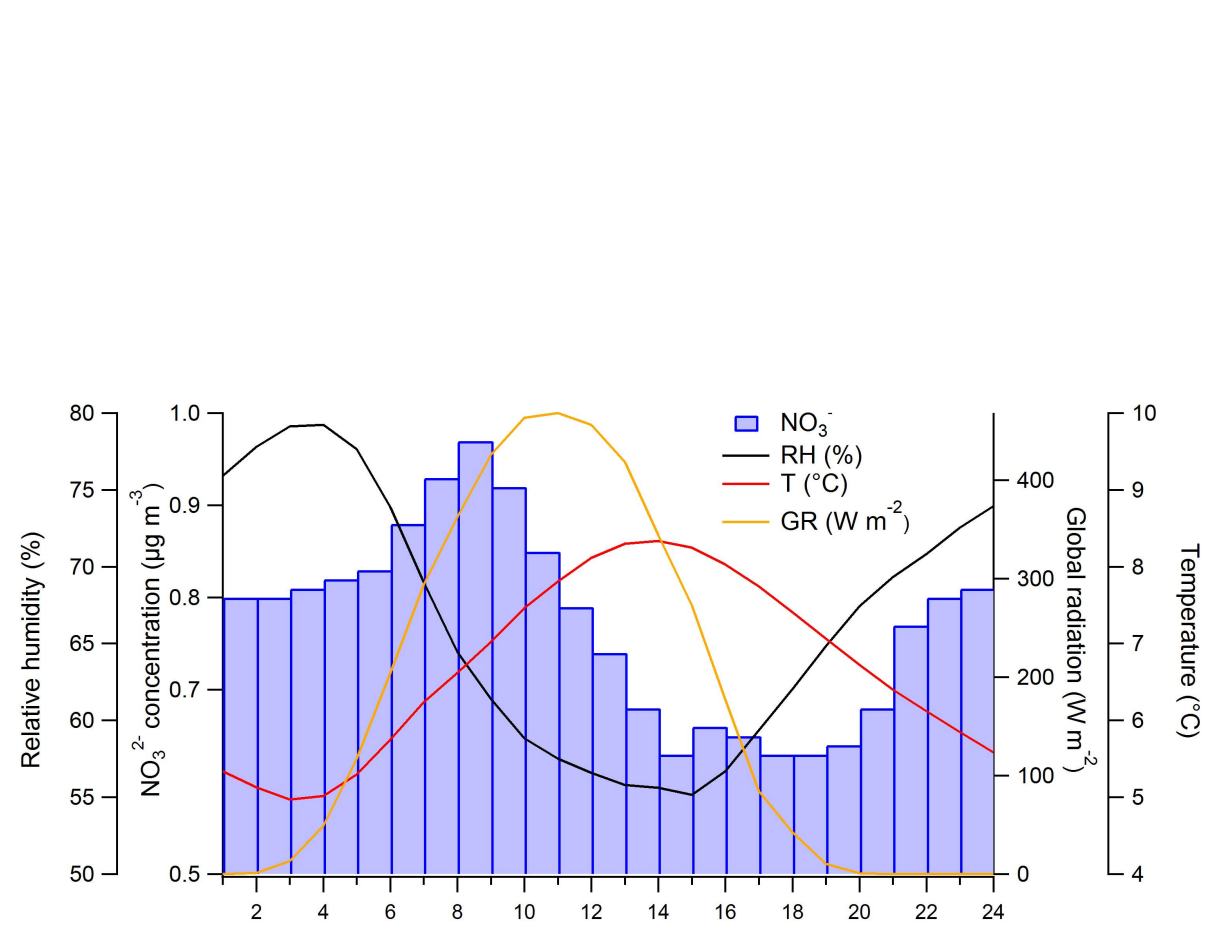

Fig. 8. The hourly-averaged nitrate concentration $\left(\mu \mathrm{g} \mathrm{m}^{-3}\right)$, global radiations $\left(\mathrm{W} \mathrm{m}^{-2}\right)$, relative humidity (\%) and temperature for each hour of day from 9 February 2006 to 28 February 2007.

\section{AMTD}

$4,6577-6614,2011$

\section{Monitoring chemical composition of ambient aerosol particles}

H. Timonen et al.

\section{Title Page}

Abstract Introduction

Conclusions

References

Tables

Figures

14

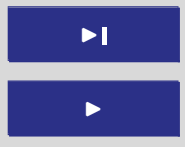

Back

Close

Full Screen / Esc

Printer-friendly Version

Interactive Discussion 

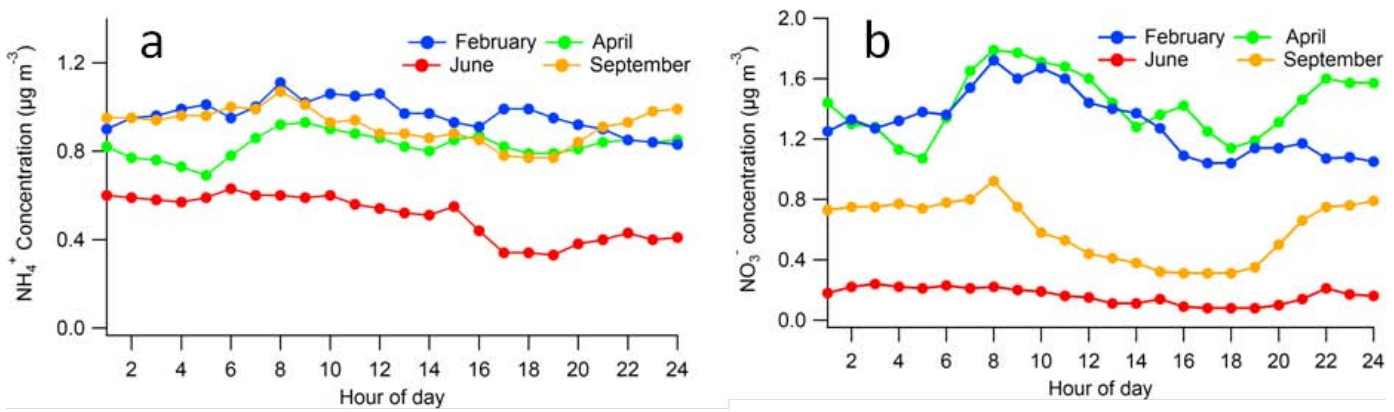

Fig. 9. The average ammonium (a) and nitrate (b) concentrations for each hour of day during the measurement campaign (9 February 2006-28 February 2007).

\section{AMTD}

$4,6577-6614,2011$

\section{Monitoring chemical composition of ambient aerosol particles}

H. Timonen et al.

\section{Title Page}

\section{Abstract}

Introduction

Conclusions

References

Tables

Figures

14

Back

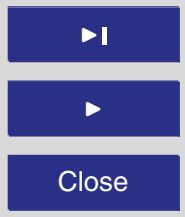

Full Screen / Esc

Printer-friendly Version

Interactive Discussion 

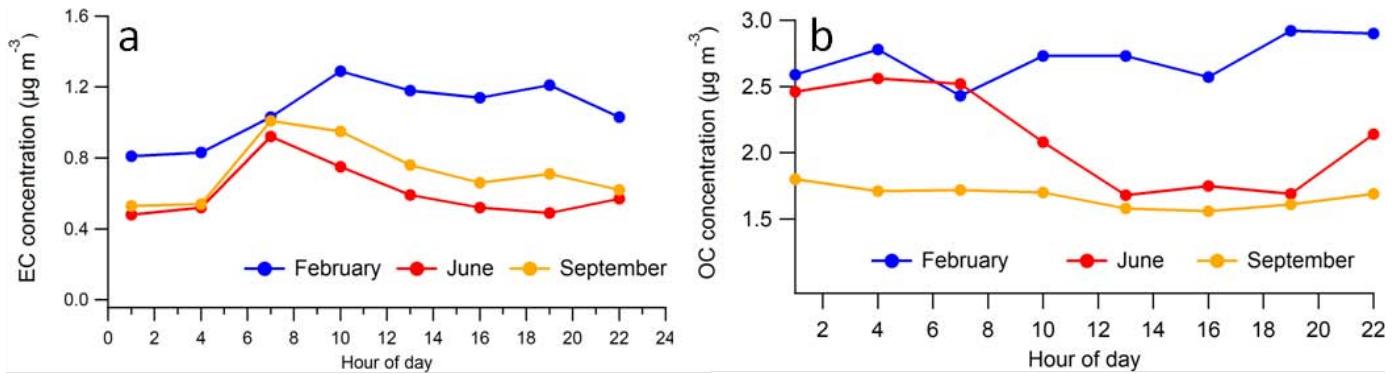

\section{AMTD}

4, 6577-6614, 2011

\section{Monitoring chemical composition of ambient aerosol particles}

H. Timonen et al.

\section{Title Page}

Abstract

Conclusions

Tables

14

Back

Introduction

References

Figures

Fig. 10. The average $E C(a)$ and $O C$ (b) and concentrations for eight time periods (three hour averages) of day during the measurement campaign (17 June 2006-28 February 2007).
Full Screen / Esc

Printer-friendly Version

Interactive Discussion 